University of South Florida

DIGITAL COMMONS

Digital Commons @ University of

@ UNIVERSITY OF SOUTH FLORIDA

South Florida

USF Accountability Reports

USF Archives

$1-1-2011$

\title{
2011 Work Plan USF Tampa
}

USF

Follow this and additional works at: https://digitalcommons.usf.edu/usf_accountability_reports

\section{Scholar Commons Citation}

USF, "2011 Work Plan USF Tampa" (2011). USF Accountability Reports. 25.

https://digitalcommons.usf.edu/usf_accountability_reports/25

This Article is brought to you for free and open access by the USF Archives at Digital Commons @ University of South Florida. It has been accepted for inclusion in USF Accountability Reports by an authorized administrator of Digital Commons @ University of South Florida. For more information, please contact digitalcommons@usf.edu. 


\section{Update to the}

\section{University of South Florida - Tampa \\ Work Plan}


Note concerning data accuracy: The Office of the Board of Governors believes that the accuracy of the data it collects and reports is paramount to ensuring accountability in the State University System. Thus, the Board Office allows university resubmissions of some data to correct errors when they are discovered. This policy can lead to changes in historical data. 


\begin{tabular}{|c|c|c|c|c|c|c|c|}
\hline \multicolumn{8}{|c|}{ University of South Florida 2010 Annual Report } \\
\hline & & & \multicolumn{5}{|c|}{ USF Tampa } \\
\hline Enrollments & $\#$ & $\%$ & \multicolumn{3}{|c|}{ Degree Programs Offered (As of Spr. 10) } & \multicolumn{2}{|r|}{ Carnegie Classification } \\
\hline $\begin{array}{c}\text { TOTAL } \\
\text { (Fall 2009) }\end{array}$ & 40,267 & $100 \%$ & \multicolumn{2}{|l|}{ TOTAL } & 233 & $\begin{array}{l}\text { Undergraduate } \\
\text { Instructional Program: }\end{array}$ & $\begin{array}{l}\text { Balanced arts \& sciences/professions, high graduate } \\
\text { coexistence }\end{array}$ \\
\hline Black & 4,776 & $12 \%$ & \multicolumn{2}{|c|}{ Baccalaureate } & 92 & \multirow{2}{*}{$\begin{array}{l}\text { Graduate Instructional } \\
\text { Program: }\end{array}$} & \multirow{2}{*}{ Comprehensive doctoral with medical/veterinary } \\
\hline Hispanic & 5,613 & $14 \%$ & \multicolumn{2}{|c|}{ Master's \& Specialist's } & 100 & & \\
\hline White & 25,064 & $62 \%$ & \multicolumn{2}{|c|}{ Research Doctorate } & 38 & Enrollment Profile: & High undergraduate \\
\hline Other & 4,814 & $12 \%$ & \multicolumn{2}{|c|}{ Professional Doctorate } & 3 & Undergraduate Profile: & $\begin{array}{l}\text { Medium full-time four-year, selective, higher transfer } \\
\text { in }\end{array}$ \\
\hline Full-Time & 26,918 & $67 \%$ & \multirow{2}{*}{$\begin{array}{c}\text { Faculty } \\
\text { (Fall 2009) }\end{array}$} & \multirow{2}{*}{$\begin{array}{l}\text { Full- } \\
\text { Time }\end{array}$} & \multirow{2}{*}{ Part-Time } & Size and Setting: & Large four-year, primarily nonresidential \\
\hline Part-Time & 13,349 & $33 \%$ & & & & \multirow{2}{*}{ Basic: } & \multirow{2}{*}{ Research Universities (very high research activity) } \\
\hline Undergraduate & 30,007 & $75 \%$ & TOTAL & 1,424 & 210 & & \\
\hline Graduate & 8,514 & $21 \%$ & Tenure/T. Track & 980 & 78 & \multirow{2}{*}{ Elective Classification: } & \multirow{2}{*}{$\begin{array}{l}\text { Community Engagement: } \\
\text { Outreach \& Partnerships }\end{array}$} \\
\hline Unclassified & 1,746 & $4 \%$ & Other Faculty/Instr. & 444 & 132 & & \\
\hline
\end{tabular}

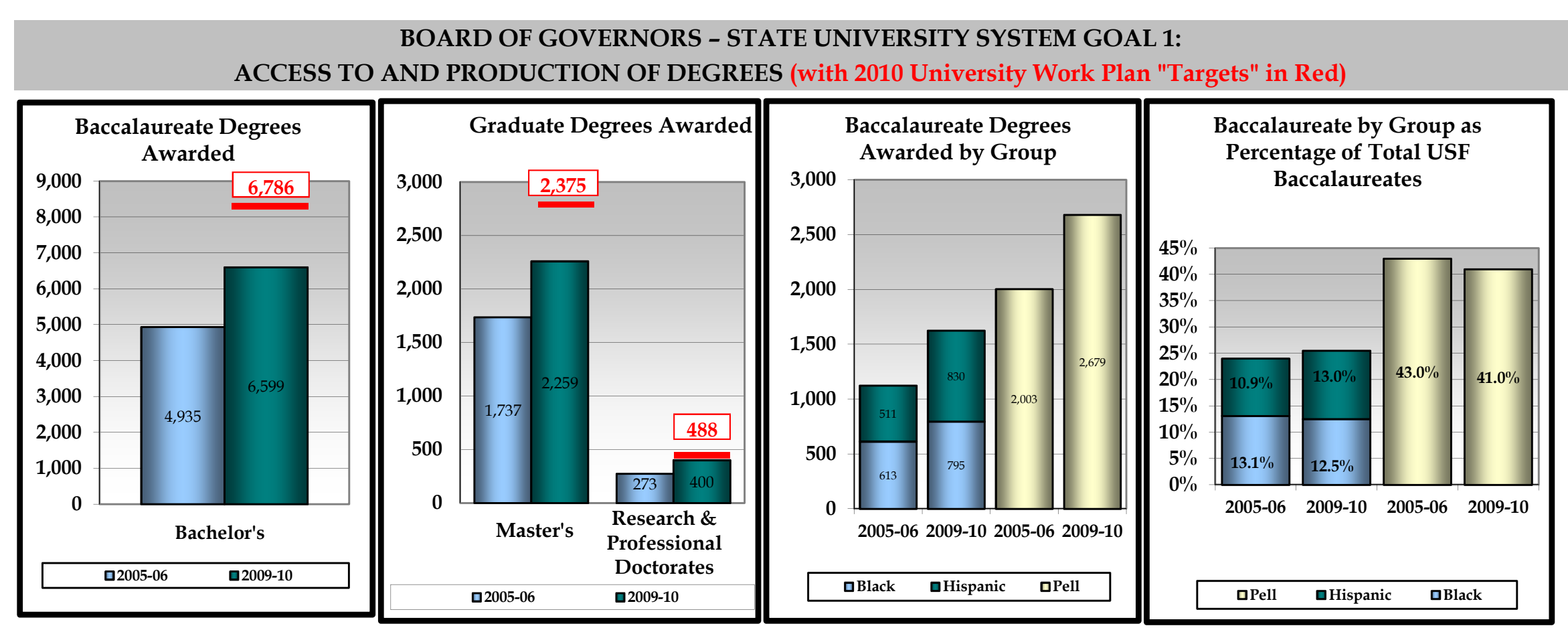

2012 - 2013 Projected Institutional Contributions in RED PRINT. 
BOARD OF GOVERNORS - STATE UNIVERSITY SYSTEM GOAL 2:

MEETING STATEWIDE PROFESSIONAL AND WORKFORCE NEEDS (with 2010 University Work Plan "Targets" in Red)

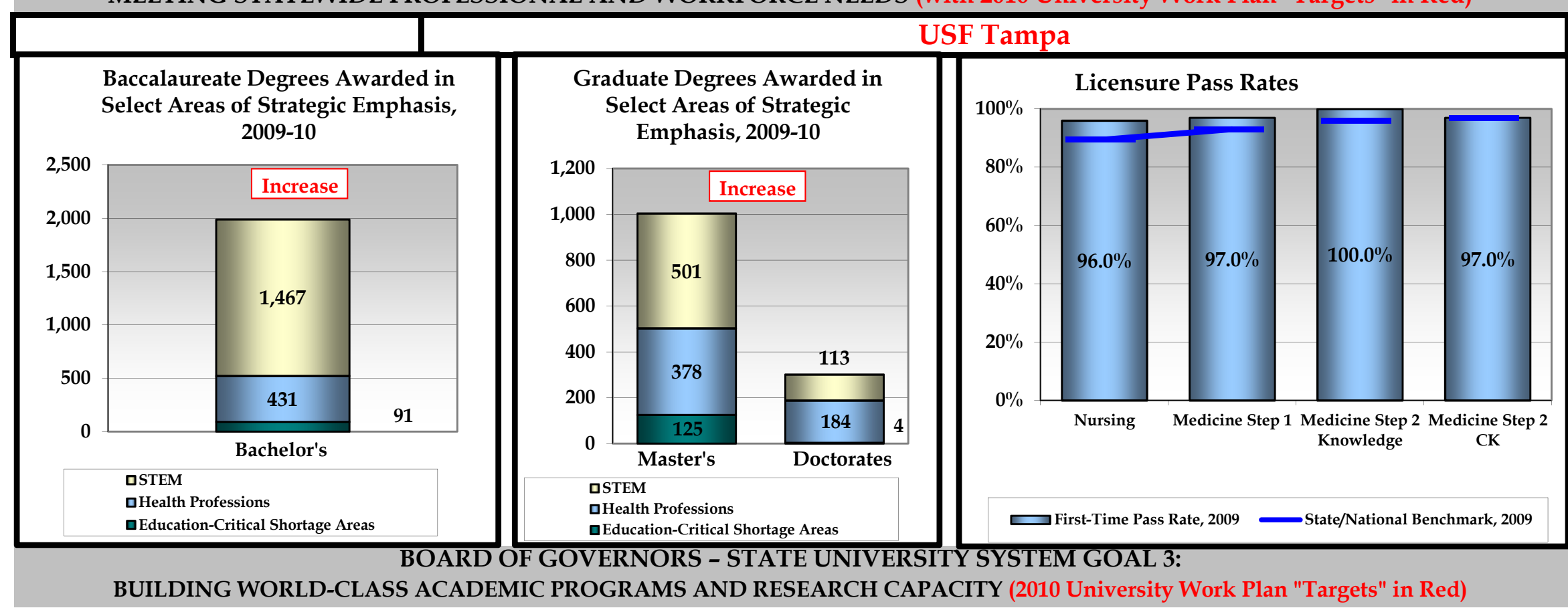

Academic Research and Development Expenditures
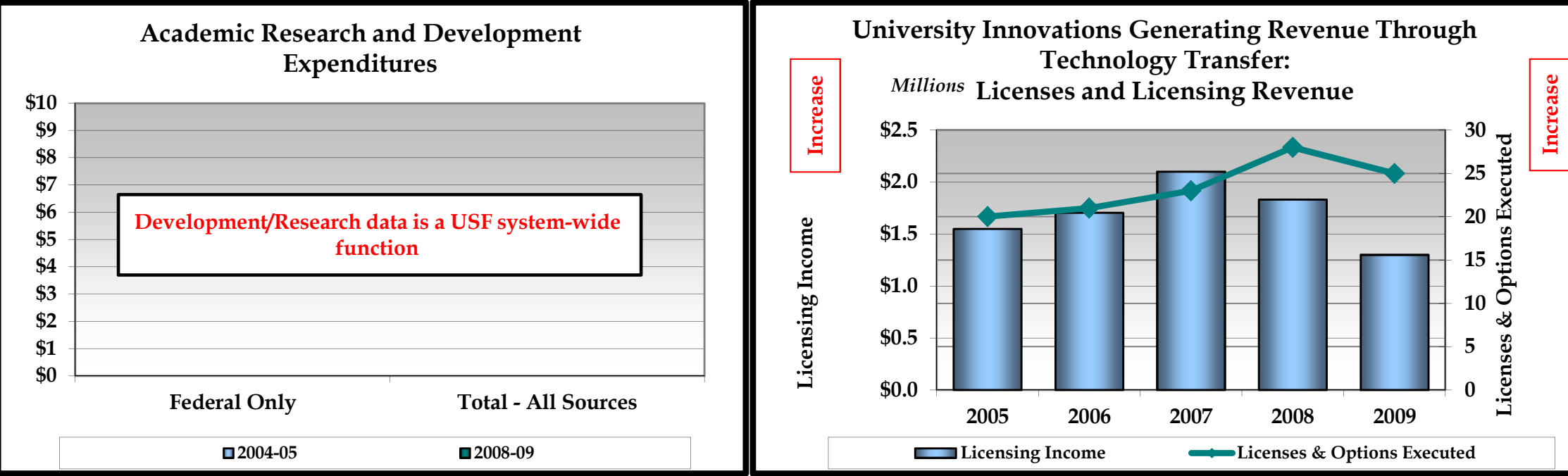

Projected Institutional Contributions in RED PRINT

(2012 - 2013 for Degrees in Areas of Strategic Emphasis; 2011 -2012 for R\&D, Licenses, and Licensing Revenue). 


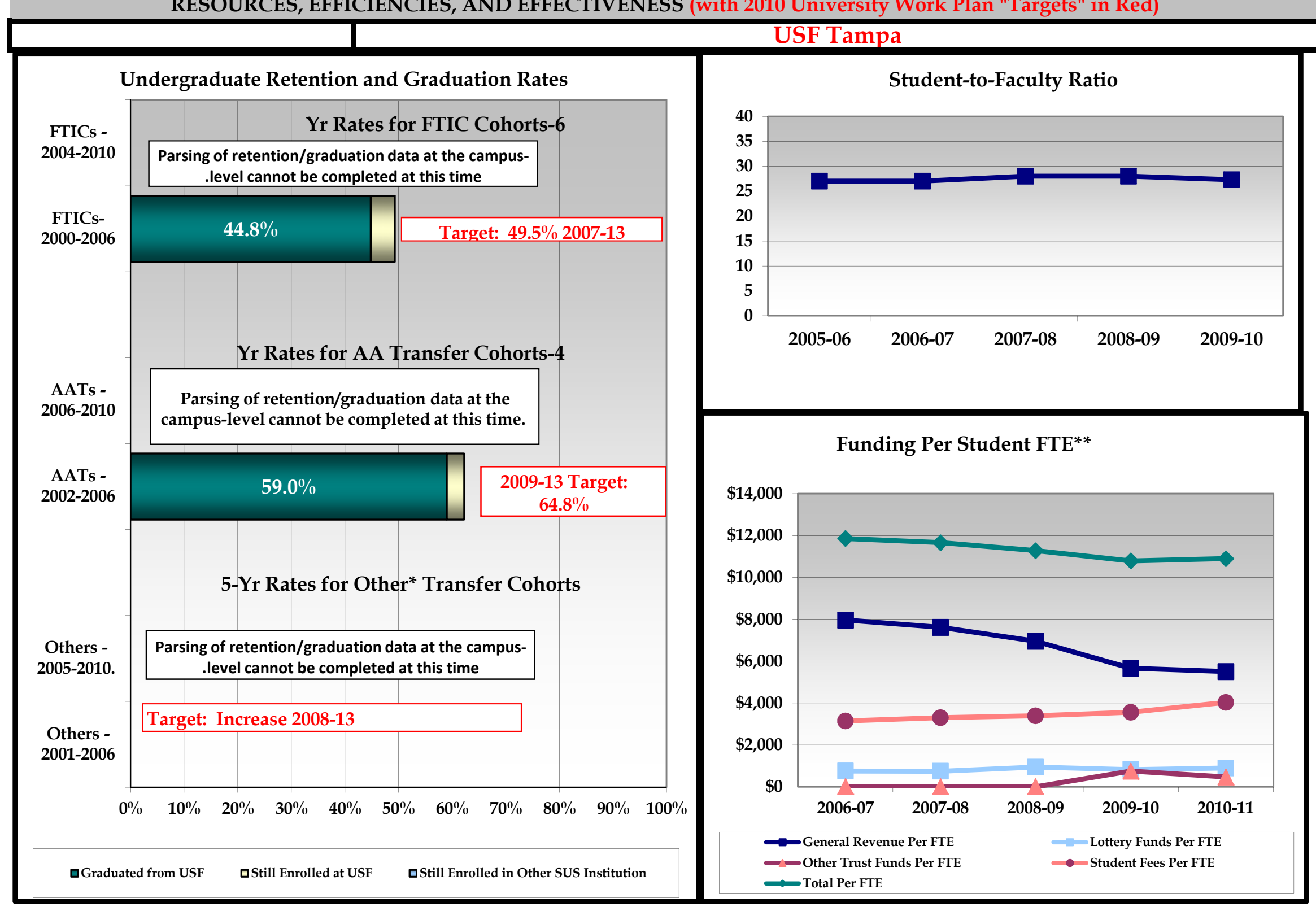

* The composition of "Other Transfer" cohorts may vary greatly by institution

** FTE for this metric uses the standard IPEDS definition of FTE, equal to 30 and by year.

credit hours for undergraduates and 24 for graduates.

Graduation Rate from SAME Institution - Projected Institutional Contributions in RED PRINT. 
Select Data Tables from the 2009-2010 Annual Report [USF Tampa]

* Peer choices should be noted. In cases in which peer data are not available for a specific metric, but are available for a related metric, an institution might want to note such in the "Comparison with Peers" row.

\begin{tabular}{|c|c|c|c|c|c|c|c|c|c|c|}
\hline Degrees Awarded & \multicolumn{2}{|l|}{ 2005-06 } & \multicolumn{2}{|c|}{ 2006-07 } & \multicolumn{3}{|c|}{ 2007-08 } & 2008-09 & \multicolumn{2}{|c|}{ 2009-10 } \\
\hline Baccalaureate & \multicolumn{2}{|l|}{4,935} & \multicolumn{2}{|c|}{5,479} & \multicolumn{3}{|c|}{5,758} & 6,073 & \multicolumn{2}{|r|}{6,599} \\
\hline Master's and Specialist & \multicolumn{2}{|l|}{1,737} & \multicolumn{2}{|c|}{1,803} & \multicolumn{3}{|c|}{2,014} & 2,096 & \multicolumn{2}{|r|}{2,259} \\
\hline Research Doctoral & \multicolumn{2}{|l|}{180} & \multirow{2}{*}{\multicolumn{2}{|c|}{$\begin{array}{l}223 \\
122\end{array}$}} & \multirow{2}{*}{\multicolumn{2}{|c|}{229}} & & 248 & \multicolumn{2}{|r|}{244} \\
\hline Professional Doctoral & \multicolumn{2}{|l|}{93} & & & & & & 154 & \multicolumn{2}{|r|}{156} \\
\hline \multirow{7}{*}{ Comparison with Peers* } & \multicolumn{10}{|c|}{$\begin{array}{l}\text { Peers: North Carolina State University, Rutgers University, Stony Brook University, University at Buffalo, University } \\
\text { of Alabama Birmingham, University of California Irvine, University of Cincinnati, University of Illinois, Chicago. } \\
\text { See http://www.ods.usf.edu/Plans/Strategic/docs/2010-10-07-Performance-Update-AAU.pdf for more } \\
\text { comparisons. } \\
\text { In 2009-10, USF awarded more baccalaureate, master's and specialist degrees than all its peers, and awarded more } \\
\text { professional doctoral degrees than all but two peers. In research doctoral degrees USF compared favorably with two } \\
\text { peers, exceeded two others, but trailed the other four. By percentage, (see parentheses) USF is similar to N.C. State and } \\
\text { Rutgers, and lower than California Irvine for baccalaureate and master's degrees, but are a little lower in doctoral degrees. }\end{array}$} \\
\hline & $\begin{array}{l}\text { Degrees } \\
\text { Awarded }\end{array}$ & USF & $\begin{array}{l}\text { N.C. } \\
\text { State }\end{array}$ & Rutgers & \begin{tabular}{l|l} 
Stony & I \\
Brook & I
\end{tabular} & $\begin{array}{l}\text { Univ. at } \\
\text { Buffalo }\end{array}$ & $\begin{array}{l}\text { Alabama } \\
\text { Birm. }\end{array}$ & $\begin{array}{c}\text { California } \\
\text { Irvine }\end{array}$ & \begin{tabular}{|c|} 
Univ. of \\
Cincinnati
\end{tabular} & \begin{tabular}{l|} 
Illinois \\
Chicago \\
\end{tabular} \\
\hline & $\mathrm{BA} / \mathrm{BS}$ & $\begin{array}{l}6599 \\
(71 \%) \\
\end{array}$ & $\begin{array}{c}4790 \\
(68 \%)\end{array}$ & $\begin{array}{l}5905 \\
(72 \%) \\
\end{array}$ & $\begin{array}{c}3525 \\
(61 \%) \\
\end{array}$ & $\begin{array}{c}4111 \\
(58 \%) \\
\end{array}$ & $\begin{array}{c}1921 \\
(52 \%) \\
\end{array}$ & $\begin{array}{c}5962 \\
(79 \%) \\
\end{array}$ & $\begin{array}{c}3796 \\
(59 \%) \\
\end{array}$ & \begin{tabular}{|c|}
3345 \\
$(53 \%)$ \\
\end{tabular} \\
\hline & MA/MS/Sp & $\begin{array}{r}2259 \\
(24 \%) \\
\end{array}$ & $\begin{array}{l}1795 \\
(25 \%)\end{array}$ & $\begin{array}{l}1690 \\
(21 \%)\end{array}$ & $\begin{array}{l}1710 \\
(30 \%)\end{array}$ & $\begin{array}{l}2043 \\
(29 \%) \\
\end{array}$ & $\begin{array}{l}1297 \\
(35 \%)\end{array}$ & $\begin{array}{l}1136 \\
(15 \%)\end{array}$ & $\begin{array}{l}1991 \\
(31 \%)\end{array}$ & $\begin{array}{l}2010 \\
(32 \%) \\
\end{array}$ \\
\hline & Res. Doc. & $\begin{array}{c}244 \\
(3 \%) \\
\end{array}$ & $\begin{array}{c}422 \\
(6 \%) \\
\end{array}$ & $\begin{array}{c}424 \\
(4 \%) \\
\end{array}$ & $\begin{array}{c}283 \\
(5 \%) \\
\end{array}$ & $\begin{array}{c}279 \\
(4 \%) \\
\end{array}$ & $\begin{array}{l}129 \\
(3 \%) \\
\end{array}$ & $\begin{array}{l}365 \\
(5 \%) \\
\end{array}$ & $\begin{array}{l}219 \\
(3 \%) \\
\end{array}$ & $\begin{array}{l}316 \\
(5 \%) \\
\end{array}$ \\
\hline & Prof. Doc. & $\begin{array}{c}156 \\
(2 \%) \\
\end{array}$ & $\begin{array}{c}79 \\
(1 \%) \\
\end{array}$ & $\begin{array}{c}218 \\
(3 \%)\end{array}$ & $\begin{array}{c}242 \\
(4 \%) \\
\end{array}$ & $\begin{array}{c}640 \\
(9 \%) \\
\end{array}$ & $\begin{array}{c}358 \\
(10 \%) \\
\end{array}$ & $\begin{array}{l}103 \\
(1 \%) \\
\end{array}$ & $\begin{array}{l}443 \\
(7 \%) \\
\end{array}$ & $\begin{array}{c}649 \\
(10 \%) \\
\end{array}$ \\
\hline & \multicolumn{10}{|c|}{ Overall performance in comparison with peers - strong. } \\
\hline \multirow{2}{*}{$\begin{array}{c}\text { Baccalaureate Degrees Awarded to } \\
\text { Underrepresented Minorities }\end{array}$} & \multicolumn{2}{|l|}{ 2005-06 } & \multicolumn{2}{|c|}{$2006-07$} & \multicolumn{2}{|r|}{ 2007-08 } & & 2008-09 & \multicolumn{2}{|c|}{ 2009-10 } \\
\hline & $\#$ & $\%$ & \# & $\%$ & $\#$ & $\%$ & $\neq$ & $\%$ & $\#$ & $\%$ \\
\hline Hispanic & 511 & 10.9 & 620 & 11.8 & 657 & 12 & & 13. & 830 & 13.0 \\
\hline Non-Hispanic Black & 613 & 13.1 & 686 & 13.1 & 723 & 13 & & 13.5 & 795 & 12.5 \\
\hline Pell Grant Recipients & 2,003 & 43.0 & 2,083 & 40.0 & 2,193 & 40 & & 38.8 & 2,679 & 41.0 \\
\hline Comparison with Peers* & $\begin{array}{l}\text { In 2009-10, USF f } \\
\text { Baccalaureate de } \\
\text { Hispanic Black st } \\
\text { available). Howe } \\
\text { recipients. }\end{array}$ & $\begin{array}{l}\text { exceedec } \\
\text { ees awar } \\
\text { dents. Sp } \\
\text { er, it is in }\end{array}$ & $\begin{array}{l}\text { ts peers } \\
\text { d at pee } \\
\text { ific data } \\
\text { ortant to }\end{array}$ & $\begin{array}{l}\text { number o } \\
\text { stitution } \\
\text { the num } \\
\text { te that } \mathrm{fc}\end{array}$ & $\begin{array}{l}\text { degrees av } \\
\text { ranged fro } \\
\text { er and perc } \\
\text { rty-one per }\end{array}$ & $\begin{array}{l}\text { warded to } \\
\text { om } 27 \text { to } 46 \\
\text { rcentage of } \\
\text { rcent of de }\end{array}$ & $\begin{array}{l}\text { Hispanic a } \\
68 \text { for Hispa } \\
\text { Pell Grant } \\
\text { grees awar }\end{array}$ & $\begin{array}{l}\text { nd Non-Hispa } \\
\text { anic students a } \\
\text { recipients on } \\
\text { ded at USF we }\end{array}$ & $\begin{array}{l}\text { anic Black stud } \\
\text { and } 148 \text { to } 466 \\
\text { peers are not } \\
\text { ent to Pell gran }\end{array}$ & $\begin{array}{l}\text { lents. } \\
\text { for Non- } \\
\text { eadily } \\
\text { tt }\end{array}$ \\
\hline
\end{tabular}




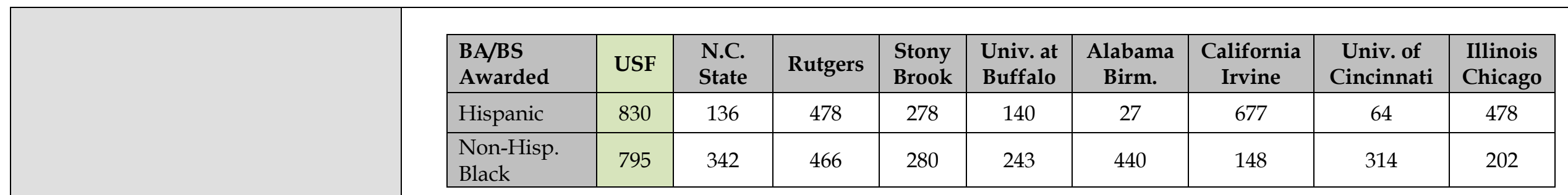

Overall performance in comparison with peers - outstanding.

\begin{tabular}{|c|c|c|c|c|c|c|c|c|c|c|}
\hline $\begin{array}{c}\text { Degrees Awarded in Select Areas } \\
\text { of Strategic Emphasis }\end{array}$ & \multicolumn{2}{|l|}{ 2005-06 } & \multicolumn{3}{|c|}{ 2006-07 } & \multicolumn{2}{|l|}{ 2007-08 } & \multicolumn{2}{|l|}{ 2008-09 } & 2009-10 \\
\hline STEM (Baccalaureate) & \multicolumn{2}{|l|}{1,049} & \multicolumn{3}{|c|}{1,199} & \multicolumn{2}{|l|}{1,231} & \multicolumn{2}{|l|}{1,324} & 1,472 \\
\hline STEM (Graduate) & \multicolumn{2}{|l|}{426} & \multicolumn{3}{|c|}{453} & \multicolumn{2}{|l|}{543} & \multicolumn{2}{|l|}{529} & 616 \\
\hline Health Professions (Baccalaureate) & \multicolumn{2}{|l|}{338} & \multicolumn{3}{|c|}{435} & \multicolumn{2}{|l|}{401} & \multicolumn{2}{|l|}{414} & 432 \\
\hline Health Professions (Graduate) & \multicolumn{2}{|l|}{384} & \multicolumn{3}{|c|}{426} & \multicolumn{2}{|l|}{420} & \multicolumn{2}{|l|}{497} & 562 \\
\hline Education-Critical Shortage (Bacc.) & \multicolumn{2}{|l|}{78} & \multicolumn{3}{|c|}{74} & \multicolumn{2}{|l|}{83} & \multicolumn{2}{|l|}{86} & 91 \\
\hline Education-Critical Shortage (Grad.) & \multicolumn{2}{|l|}{88} & \multicolumn{2}{|r|}{116} & & \multicolumn{2}{|l|}{112} & \multicolumn{2}{|l|}{140} & 129 \\
\hline \multirow{5}{*}{ Comparison with Peers* } & \multicolumn{10}{|c|}{$\begin{array}{l}\text { In 2009-10, USF awarded more STEM baccalaureate and health baccalaureate degrees than all but two of its peer } \\
\text { institutions. In health graduate degrees awarded, USF exceeded four of its peers; the number of graduate health degrees } \\
\text { awarded by its peers ranged from } 89 \text { to 1,102. Comparable data on STEM graduate and educational degrees awarded ar } \\
\text { not readily available. }\end{array}$} \\
\hline & $\begin{array}{l}\text { Degrees } \\
\text { Awarded }\end{array}$ & USF & $\begin{array}{l}\text { N.C. } \\
\text { State }\end{array}$ & Rutgers & $\begin{array}{l}\text { Stony } \\
\text { Brook }\end{array}$ & $\begin{array}{l}\text { Univ. at } \\
\text { Buffalo }\end{array}$ & $\begin{array}{l}\text { Alabama } \\
\text { Birm. }\end{array}$ & $\begin{array}{l}\text { California } \\
\text { Irvine }\end{array}$ & $\begin{array}{c}\text { Univ. of } \\
\text { Cincinnati }\end{array}$ & $\begin{array}{l}\text { Illinois } \\
\text { Chicago }\end{array}$ \\
\hline & $\begin{array}{l}\text { STEM } \\
\text { BA/BS }\end{array}$ & 1,472 & 1,894 & 1,340 & 832 & 959 & 295 & 1,687 & 638 & 812 \\
\hline & $\begin{array}{l}\text { Health } \\
\text { BA/BS }\end{array}$ & 432 & $\mathrm{n} / \mathrm{a}$ & 82 & 658 & 263 & 430 & 235 & 646 & 205 \\
\hline & Health Grad & 562 & 89 & 251 & 519 & 598 & 949 & 109 & 691 & 1,102 \\
\hline
\end{tabular}

Overall performance in comparison with peers - outstanding.

\begin{tabular}{|c|c|c|c|c|c|c|c|c|c|c|}
\hline \multirow{2}{*}{$\begin{array}{l}\text { Undergraduate Retention and } \\
\text { Graduation Rates from Same } \\
\text { Institution }\end{array}$} & \multicolumn{2}{|c|}{ By 2006} & \multicolumn{2}{|c|}{ By 2007} & \multicolumn{2}{|c|}{ By 2008} & \multicolumn{2}{|c|}{ By 2009} & \multicolumn{2}{|c|}{ By 2010} \\
\hline & Grad & $\begin{array}{l}\text { Still } \\
\text { Enr }\end{array}$ & Grad & $\begin{array}{l}\text { Still } \\
\text { Enr }\end{array}$ & Grad & $\begin{array}{l}\text { Still } \\
\text { Enr }\end{array}$ & Grad & $\begin{array}{l}\text { Still } \\
\text { Enr }\end{array}$ & Grad & $\begin{array}{l}\text { Still } \\
\text { Enr }\end{array}$ \\
\hline Fed.Def.: 6-Yr Rates Full-Time FTICs & $48.1 \%$ & $\mathrm{n} / \mathrm{a}$ & $48.8 \%$ & $\mathrm{n} / \mathrm{a}$ & $47.5 \%$ & $\mathrm{n} / \mathrm{a}$ & $48.1 \%$ & $\mathrm{n} / \mathrm{a}$ & $51.0 \%$ & $\mathrm{n} / \mathrm{a}$ \\
\hline SUS Def.: 6-Yr Rates - FTICS & \multicolumn{10}{|c|}{ See USF System plan; parsing of retention/grad rates using SUS methodology n/a by campus-level; as reported in 2010 Annual Repor } \\
\hline SUS Def.: 4-Yr F & \multicolumn{10}{|c|}{ See USF System plan; parsing of retention/grad rates using SUS methodology n/a by campus-level; as reported in 2010 Annual Report } \\
\hline SUS Def.: 5-Yr Rates - Others & ee USF S & 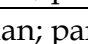 & retent & d & SUS n & 60 & ampu & is re & 2010 & Report \\
\hline
\end{tabular}




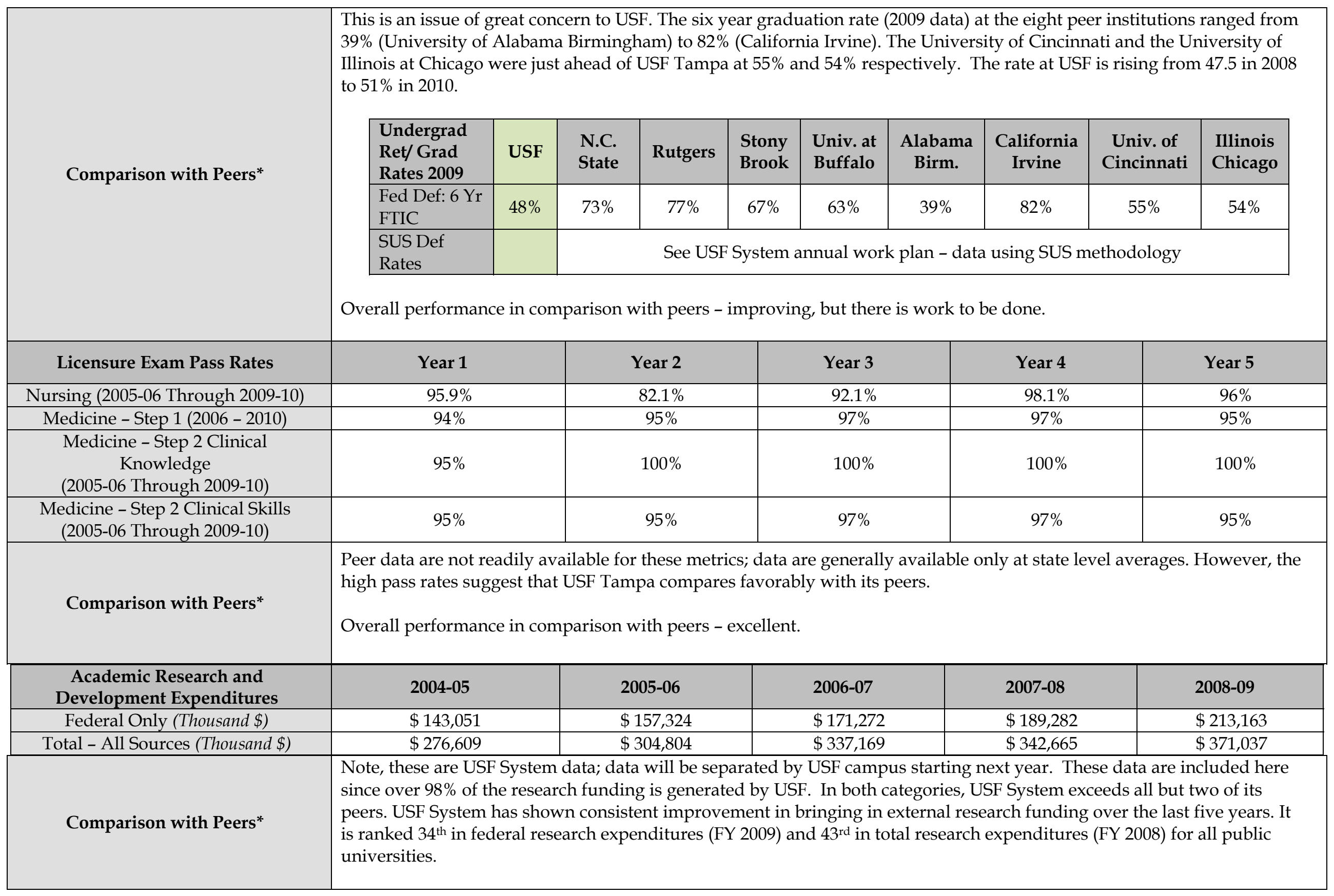




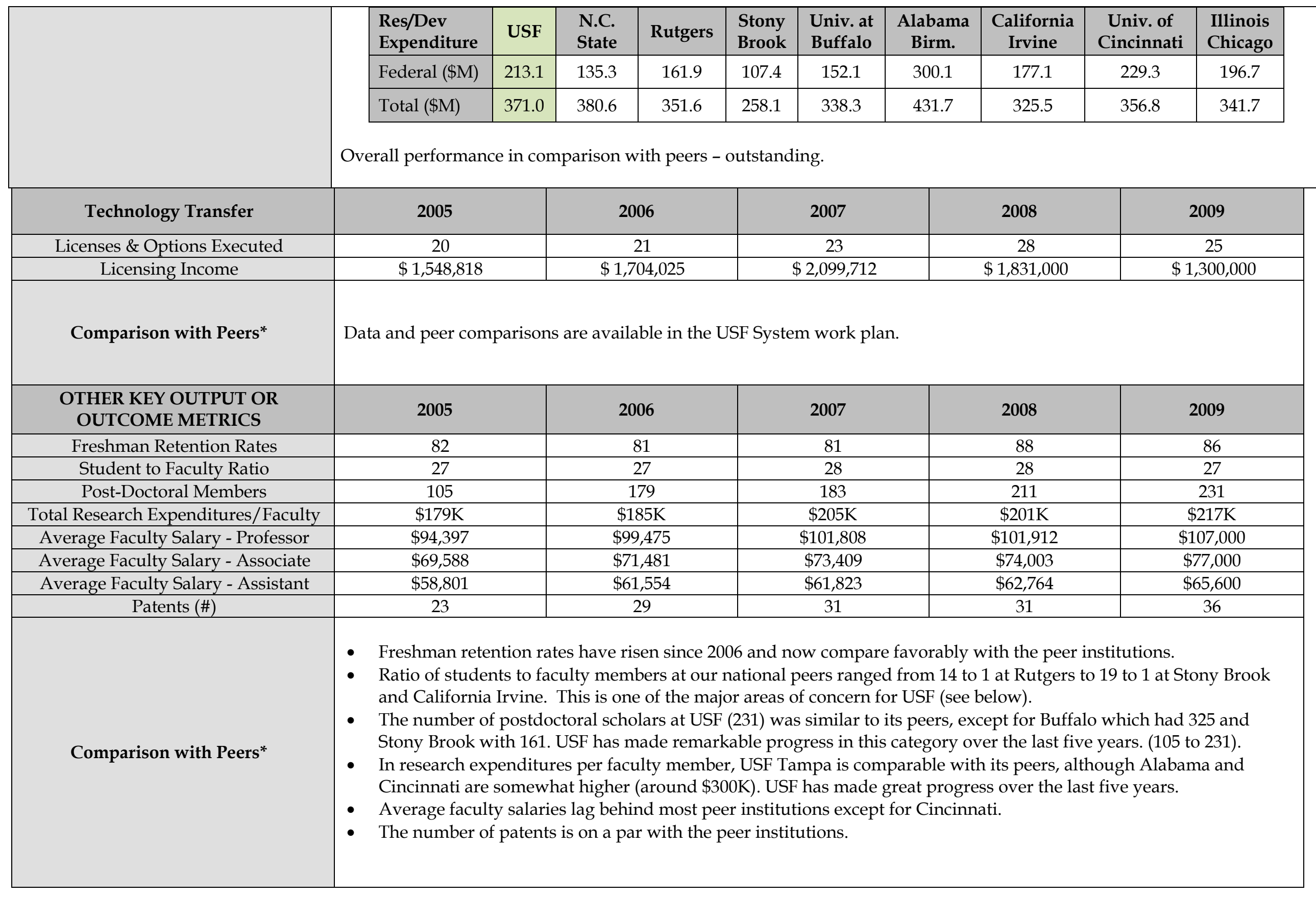




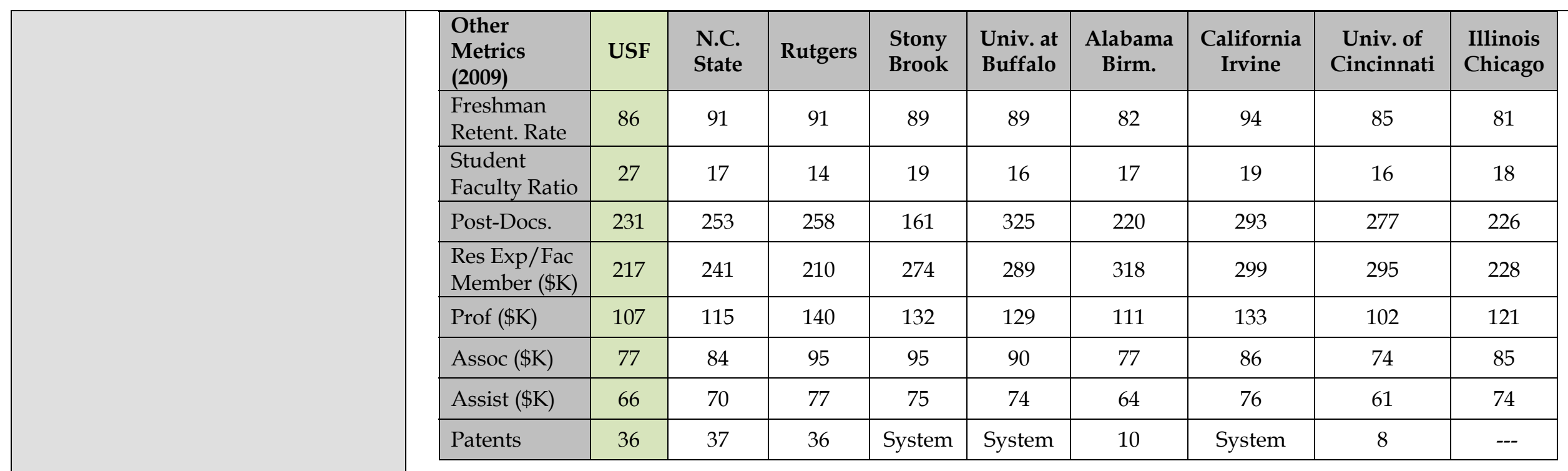

Overall performance in comparison with peers - strong to outstanding.

\section{Based on Review of Data Trends on Key Output or Outcome Metrics Identified Here and/or in Annual Report,} Three (3) Areas of Concern/Areas Needing Improvement

(1) Graduation Rates: While the six-year graduation rate for FTIC students has steadily improved since 2008 at USF, from $47.5 \%$ to $51.6 \%$ in 2010, it still remains relatively low in comparison with some of our peers. The strategic initiative highlighting student success is now paying benefits with higher retention rates at each year and with more students graduating in a timely manner. This initiative continues to be a very high priority for USF.

(2) Student to Faculty Ratio: The student to faculty ratio is low (27 to 1) in comparison with our peers, public AAU institutions, and AAU prospects (http://www.ods.usf.edu/Plans/Strategic/docs/2010-10-07-Performance-Update-AAU.pdf). The mean for public AAU institutions and AAU prospects is around 16 to 1 . While USF has made remarkable progress and compares favorably with its peers and with many AAU institutions in most of its achievements, student success is somewhat stymied by lack of faculty members.

(3) Academic Goals and University Infrastructure: An important challenge to USF is maintaining and developing its infrastructure to ensure high quality academic performance. This entails not only maintenance of its physical plant but also its academic support structures. The library, as it moves towards being a member of the Association of Research Libraries needs special attention, as too does the enhancement of the technological resources that lead to greater innovation. The support for students also creates challenges at USF. USF lags its peer institutions and many other Florida universities in dollars per student FTE. While institutional efficiencies are already very high, additional resources would greatly enhance student success, further employment opportunities and contribute to new Florida initiatives. 


\section{UPDATES TO 2010 UNIVERSITY WORK PLAN [USF]}

[Please identify briefly any critical changes only to information provided in the 2010 University Work Plan that was not updated in the 2009-2010 Annual Report regarding the institution's strategic plan; institutional mission, vision, and strategic directions for the next five to ten years; current or aspirational peer institutions; windows of opportunity; or unique challenges.]

\section{Developments consistent with the 2010 goals:}

Moving Towards AAU Eligibility: Reflecting the institution's goals of becoming eligible for membership in the Association of American Universities, USF continues to make considerable progress. The strategic plan documents the metrics used to measure success, for which the institution is held accountable by Trustees. http://www.ods.usf.edu/Plans/Strategic/docs/2010-10-07-Performance-Update-AAU.pdf (http://www.ods.usf.edu/Plans/PPA/matrix.htm ).

Revenue Enhancement - Public-Private Partnerships: USF continues to enhance its revenue through development of external funding, private giving, technology transfer and public-private partnerships. USF monitors public-private partnerships for increases in external funding, patents and licenses.

Global Initiatives: USF has seen considerable increases in its global activities, international faculty exchanges, recruitment of fee-paying international students and student study abroad programs, thus adding to Florida's place in the global economy and employment opportunities. Its partnership with INTO has internationalized the campus. School for Global Sustainability has been established and will be developed further. USF World will be further enhanced.

\section{New Opportunities:}

Technological and Innovative Advances - Marine and Coastal Environments - Health: An identified area of strategic focus, Marine Science and Coastal Technologies represents a key area, as demonstrated by the rapid response to the Gulf Oil spill of 2010. Technological advances have been further enhanced through the innovative USF Health initiatives such as the Center for Advanced Medical Learning and Simulation.

Community Engagement: Establish a unified institutional structure to facilitate community engagement, social enterprise, and global collaborations in education, research and service learning, including managing fiscal and human resources for student exchange, study abroad and international field placement programs, and faculty research, teaching, outreach and professional development opportunities.

USF and the USF System: USF is an integral part of the evolving USF System. It works closely with the other campuses to enhance the mission of the USF System and helps facilitate the distinctive missions of all four campuses. All four institutions have separate IPEDS; USF (in Tampa) and USF St. Petersburg are accredited by SACS; USF Sarasota-Manatee should be SACS accredited in June 2011 and USF Polytechnic in 2012. In the Carnegie Foundation for the Advancement of Teaching classification: USF is a doctoral university with very high research activity; USF ST. Petersburg, USF Sarasota-Manatee and USF Polytechnic are each classified as masters, medium level. USF and USF St. Petersburg are also Carnegie Community Engaged institutions. The members of the USF System together provide:

- Enhanced access for students

- Distinctiveness while optimizing potential

- Greater choice to meet student and academic needs

- Broader advocacy

- Efficiencies, both academic and economic

- Commitment to meeting local needs

- Leveraging our combined strength through collaboration

- A unified brand yielding identity and impact. 
CAVP Academic Coordination Project (List degree programs recommended for new collaborative or joint delivery model or other corrective action, as well as any degree programs recommended for continuation but for which university and Board staff have not reached agreement on the sufficiency of the rationale.)

\begin{tabular}{|c|c|c|c|c|}
\hline $\begin{array}{l}\text { Program } \\
\text { Level }\end{array}$ & $\begin{array}{l}\text { 6-Digit } \\
\text { CIP } \\
\text { Code }\end{array}$ & Program Title & $\begin{array}{c}\text { Category (i.e., } \\
\text { Collaborative Model, } \\
\text { Corrective Action, or } \\
\text { Proposed } \\
\text { Continuation) }\end{array}$ & Proposed Action \\
\hline $\mathrm{D}$ & 14.0501 & Biomedical Engineering & $\begin{array}{l}\text { This program is in a } \\
\text { unit that is highly } \\
\text { productive; Chemical } \\
\text { Engineering. The } \\
\text { department awards } \\
\text { degrees for BS, MS and } \\
\text { Ph.D. in Chemical } \\
\text { Engineering. }\end{array}$ & $\begin{array}{l}\text { This program started in } 2005 \text { with } \\
\text { no new resources and has produced } \\
1.6 \text { degrees per year, on average. } \\
\text { Since } 2009 \text { the college has hired four } \\
\text { new faculty in this program. With } \\
\text { increased involvement of the } \\
\text { Medical School we expect the } \\
\text { number of graduates to increase } \\
\text { beyond the threshhold. }\end{array}$ \\
\hline $\mathrm{D}$ & 14.1901 & Mechanical Engineering & $\begin{array}{l}\text { The program is in a unit } \\
\text { that awards a high } \\
\text { number of degrees at } \\
\text { the BS and MS level. } \\
\text { The program also } \\
\text { delivers a high number } \\
\text { of student credit hours } \\
\text { and currently it has a } \\
\text { high number of } \\
\text { enrolled Ph.D. students. }\end{array}$ & $\begin{array}{l}\text { There is a corrective action plan in } \\
\text { place to improve graduation rates. } \\
\text { Twenty-one new Ph.D. students } \\
\text { were admitted to the department } \\
\text { during AY 2010-2011. Current } \\
\text { Ph.D. enrollment is close to 40; } \\
\text { going forward, this will result in } \\
\text { significant increase in Ph.D. degrees } \\
\text { awarded. }\end{array}$ \\
\hline $\mathrm{D}$ & 45.0401 & Criminology & $\begin{array}{l}\text { The program is in a unit } \\
\text { that serves a large } \\
\text { number of } \\
\text { undergraduate students } \\
\text { (1200) and graduate } \\
\text { students (99) with only } \\
12 \text { faculty. Faculty } \\
\text { scholarly productivity } \\
\text { is ranked in top ten for } \\
\text { the discipline. }\end{array}$ & $\begin{array}{l}\text { Curricular revisions are underway } \\
\text { to: implement a 3-member faculty } \\
\text { committee to promote timely degree } \\
\text { completion; reviewing departmental } \\
\text { policies regarding timeline for } \\
\text { degree completion. A plan is in } \\
\text { place to increase faculty hiring. In } \\
\text { addition, a three-year plan will be } \\
\text { developed to increase graduate } \\
\text { stipends }\end{array}$ \\
\hline $\mathrm{D}$ & 50.0901 & Music, General & $\begin{array}{l}\text { This is the Ph.D. } \\
\text { program in Music } \\
\text { Education. }\end{array}$ & $\begin{array}{l}\text { The program has increased the } \\
\text { number of enrolled students and } \\
\text { additional recruitment positions the } \\
\text { program to meet and exceed the } \\
\text { minimum requirement for average } \\
\text { graduation rate. }\end{array}$ \\
\hline EdS & 13.0401 & $\begin{array}{l}\text { Education } \\
\text { Administration/Ldrshp, Gnrl }\end{array}$ & $\begin{array}{l}\text { There is no additional } \\
\text { pecuniary or non- } \\
\text { pecuniary cost to the } \\
\text { department as these } \\
\text { students enroll in the } \\
\text { same courses as those } \\
\text { pursuing a doctorate; in } \\
\text { cases where doctoral } \\
\text { students fail to make } \\
\text { satisfactory progress in }\end{array}$ & $\begin{array}{l}\text { We are in the process of submitting } \\
\text { a new folio to the Florida } \\
\text { Department of Education that will } \\
\text { add principal certification track to } \\
\text { our Educational Specialist degree. } \\
\text { This will replace our current } \\
\text { principal certificate modified } \\
\text { program which is a non-degree } \\
\text { program. We anticipate an increase } \\
\text { in enrollment with this change. }\end{array}$ \\
\hline
\end{tabular}




\begin{tabular}{|c|c|c|c|c|}
\hline & & & $\begin{array}{l}\text { their program, the } \\
\text { specialist degree } \\
\text { provides an alternative } \\
\text { to non-degree } \\
\text { completion; the } \\
\text { educational specialists } \\
\text { degree prepares } \\
\text { students to teach at the } \\
\text { community college } \\
\text { level without attaining } \\
\text { the doctorate; and, the } \\
\text { educational specialist } \\
\text { degree provides an } \\
\text { avenue for students } \\
\text { who already have a } \\
\text { master's degree, but do } \\
\text { not want to pursue a } \\
\text { doctorate. }\end{array}$ & \\
\hline M & 05.0102 & American Studies & $\begin{array}{l}\text { The department is in } \\
\text { the midst of executing a } \\
\text { plan to grow this } \\
\text { program beyond critical } \\
\text { levels as part of their } \\
\text { efforts to "re-invent" } \\
\text { American Studies. This } \\
\text { also provides excellent } \\
\text { support for the } \\
\text { university's newly } \\
\text { articulated global } \\
\text { strategy. }\end{array}$ & $\begin{array}{l}\text { We expect enrollment to exceed } \\
\text { required levels within two years. } \\
\text { This program also provides } \\
\text { significant support for the } \\
\text { university's general education } \\
\text { program in the areas of Humanities } \\
\text { and Fine Arts. }\end{array}$ \\
\hline $\mathrm{M}$ & 05.0207 & Women Studies & $\begin{array}{l}\text { The Department of } \\
\text { Women's Studies at } \\
\text { USF has undergone a } \\
\text { radical transformation } \\
\text { in the past year with the } \\
\text { renaming of the } \\
\text { department (now the } \\
\text { more inclusive } \\
\text { Women's and Gender } \\
\text { Studies) and all new } \\
\text { faculty. }\end{array}$ & $\begin{array}{l}\text { In years past it had a large and } \\
\text { successful Master's Program and } \\
\text { within a year or two it will have one } \\
\text { once again. The department is } \\
\text { currently aggressively recruiting } \\
\text { affiliate faculty and new students. }\end{array}$ \\
\hline
\end{tabular}


New Academic Degree Program Proposals - Next Three Years (Program development goals need to align with the institutional strategic plan and System priorities.)

\begin{tabular}{|c|c|c|c|c|}
\hline $\begin{array}{c}\text { Proposed Date of } \\
\text { Submission to } \\
\text { University Board of } \\
\text { Trustees } \\
\end{array}$ & $\begin{array}{l}\text { Program } \\
\text { Level }\end{array}$ & $\begin{array}{l}\text { 6-Digit CIP } \\
\text { Code }\end{array}$ & Program Title & $\begin{array}{c}\text { Comments } \\
\text { (Including Proposed } \\
\text { Implementation Date) }\end{array}$ \\
\hline Dec 2011 & B & 51.000 & Health Science & 2012 Health \\
\hline Dec 2011 & B & 51.1599 & Behavioral Healthcare & 2012 Health \\
\hline Dec 2011 & M & 09.0903 & Advertising & 2012 \\
\hline Dec 2011 & M & 30.2001 & $\begin{array}{c}\text { Diplomacy and Strategic } \\
\text { Studies }\end{array}$ & 2012 Global \\
\hline Spring 2012 & M & 31.0504 & Sport Management & 2012 \\
\hline Dec 2011 & M & 51.2707 & Health Informatics & 2012 Health \\
\hline Dec 2011 & $\mathrm{M}$ & 26.0907 & $\begin{array}{c}\text { Diabetes and AutoImmune } \\
\text { Diseases }\end{array}$ & 2012 Health \\
\hline Dec 2011 & $\mathrm{RD}$ & 14.1407 & Environmental Engineering & 2012 STEM \\
\hline Dec 2011 & $\mathrm{RD}$ & 42.2814 & Applied Behavioral Analysis & 2012 Health \\
\hline Dec 2011 & $\mathrm{RD}$ & 51.2314 & Rehabilitation Sciences & 2013 Health \\
\hline
\end{tabular}




\section{Enrollment Planning}

Please explain briefly any planned changes in enrollment patterns in the next five years, with rationale (e.g., more emphasis on enrolling FCS AA transfers; enrollment of more out-of-state students; enrollment of more FTICs as the institution builds out a more residential experience for undergraduates; maintain undergraduate enrollment with more growth at graduate level to align with institutional mission; plan to maintain current enrollment with more emphasis on improving graduation rates; etc.).

USF has an unduplicated head count enrollment for Fall 2010 of 40,429, of which 9,466 (23.4\%) is at the graduate level. The over-riding, long-term goal of the institution is to maintain current enrollment levels by increasing graduate enrollment to $25 \%$ and slightly reducing undergraduate headcount enrollment. The other institutions within the USF System will then meet the needs of undergraduates in the west-central Florida region. The estimated student FTE at USF for 2010-11 is 25,542 of which graduates account for 5,154 (20\%); the plan is to increase institutional efficiency by reducing the ratio of FTE to headcount for all academic levels. which current stands at 1 to 1.58 .

1. Annual FTE enrollment plans by level, site, and residency for tuition purposes in the format provided in the template on the next pages.

2. These are only to include fundable FTE enrollments. So, for example, out-of-state profile admits should not be included in the out-of-state data.

3. Remember that Pharm.D., Law, and other Professional Doctorates (per the recently changed IPEDS definitions) should be counted as Grad II enrollments.

4. An explanation of over-enrollment is required for any level in which the 2010-11 funded enrollment plan lagged actual 2010-11 enrollment by more than 5\% (Section 1011.90, F.S.).

With the absence of increased state appropriations for growth, the funded plan has not grown at the same pace as actual enrollment. Additional reasons for the enrollment growth are various, and include the following:

- USF's enrollment response reflects significant progress in addressing SUS priorities, including: providing increased access and production of degrees which is reflected in increases at all levels, increasing world-class research efforts (which partially explains the large increase in Grad II numbers), and meeting targeted program and critical statewide work force needs, such as health care (including nursing and pharmacy), engineering and technology, and education (all of which have increased enrollment at USF).

- A permanent revenue neutral shift would reduce magnitude of variance. And obviously, the lack of distribution of funded FTE by the Legislature for three years is a major factor. 


\begin{tabular}{|c|c|c|c|c|c|c|c|c|}
\hline \multicolumn{9}{|c|}{$\begin{array}{l}\text { Enrollment Plan Proposal - All State-Fundable FTE Enrollments } \\
\text { (Except Medical/Dental/Veterinary Enrollments) }\end{array}$} \\
\hline $\begin{array}{l}\text { For entire } \\
\text { institution }\end{array}$ & Funded & Estimated & Funded & Estimated & Estimated & Estimated & Estimated & \multirow{2}{*}{$\begin{array}{c}\text { 5-Year } \\
\text { Projected } \\
\text { Average } \\
\text { Annual } \\
\text { Growth } \\
\text { Rate }\end{array}$} \\
\hline FTE & $2010-11$ & $2010-11$ & 2011-12 & 2011-12 & $2012-13$ & 2014-15 & 2016-17 & \\
\hline $\begin{array}{c}\text { FL } \\
\text { Resident } \\
\text { Lower }\end{array}$ & 8,617 & 8,052 & 8,617 & 8,000 & 8,000 & 8,000 & 8,000 & $0.0 \%$ \\
\hline $\begin{array}{c}\text { FL } \\
\text { Resident } \\
\text { Upper }\end{array}$ & 9,999 & 10,264 & 9,999 & 10,400 & 10,556 & 10,873 & 11,199 & $1.5 \%$ \\
\hline $\begin{array}{c}\text { FL } \\
\text { Resident } \\
\text { Grad I }\end{array}$ & 2,672 & 2,341 & 2,672 & 2,500 & 2,600 & 2,808 & 3,033 & $3.9 \%$ \\
\hline $\begin{array}{c}\text { FL } \\
\text { Resident } \\
\text { Grad II }\end{array}$ & 623 & 786 & 623 & 800 & 832 & 899 & 970 & $3.9 \%$ \\
\hline $\begin{array}{l}\text { Total FL } \\
\text { Resident }\end{array}$ & 21,911 & 21,443 & 21,911 & 21,700 & 21,988 & 22,579 & 23,202 & $1.3 \%$ \\
\hline $\begin{array}{c}\text { Non-Res. } \\
\text { Lower }\end{array}$ & & 372 & & 428 & 492 & 566 & 651 & $8.7 \%$ \\
\hline $\begin{array}{c}\text { Non-Res. } \\
\text { Upper }\end{array}$ & & 361 & & 370 & 385 & 400 & 416 & $2.4 \%$ \\
\hline $\begin{array}{c}\text { Non-Res. } \\
\text { Grad I }\end{array}$ & & 330 & & 340 & 357 & 375 & 394 & $3.0 \%$ \\
\hline $\begin{array}{l}\text { Non-Res. } \\
\text { Grad II }\end{array}$ & & 427 & & 430 & 440 & 450 & 460 & $1.4 \%$ \\
\hline $\begin{array}{l}\text { Total Non- } \\
\text { Res. }\end{array}$ & 1,302 & 1,490 & 1,302 & 1,373 & 1,559 & 1,787 & 1,920 & $6.9 \%$ \\
\hline $\begin{array}{l}\text { Total } \\
\text { Lower }\end{array}$ & & & & & & & & \\
\hline $\begin{array}{l}\text { Total } \\
\text { Upper }\end{array}$ & & 8,424 & & 8,428 & 8,492 & 8,566 & 8,651 & $0.5 \%$ \\
\hline $\begin{array}{c}\text { Total Grad } \\
\text { I }\end{array}$ & & 10,625 & & 10,770 & 10,941 & 11,273 & 11,615 & $1.5 \%$ \\
\hline $\begin{array}{l}\text { Total Grad } \\
\text { II }\end{array}$ & & 2,671 & & 2,840 & 2,957 & 3,183 & 3,426 & $3.8 \%$ \\
\hline Total FTE & & 1,213 & & 1,230 & 1,272 & 1,349 & 1,430 & $3.1 \%$ \\
\hline
\end{tabular}




\begin{tabular}{|c|c|c|c|c|c|c|c|c|}
\hline \multicolumn{9}{|c|}{ Enrollment Plan Proposal - Medical/Dental/Veterinary State-Fundable Enrollments } \\
\hline $\begin{array}{l}\text { For entire } \\
\text { institution }\end{array}$ & Funded & Estimated & Funded & Estimated & Estimated & Estimated & Estimated & \multirow{2}{*}{$\begin{array}{c}5-\text { Year } \\
\text { Projected } \\
\text { Average } \\
\text { Annual } \\
\text { Growth } \\
\text { Rate }\end{array}$} \\
\hline Headcount & 2010-11 & $2010-11$ & 2011-12 & 2011-12 & $2012-13$ & 2014-15 & 2016-17 & \\
\hline $\begin{array}{c}\text { FL Resident } \\
\text { Medical } \\
\text { Headcount }\end{array}$ & 480.0 & 458.0 & 480.0 & 460.0 & 460.0 & 460.0 & 460.0 & $0.2 \%$ \\
\hline $\begin{array}{c}\text { Non-Res. } \\
\text { Medical } \\
\text { Headcount }\end{array}$ & & 17.0 & & 20.0 & 20.0 & 20.0 & 20.0 & $0.2 \%$ \\
\hline $\begin{array}{c}\text { Total Medical } \\
\text { Headcount }\end{array}$ & 480.0 & 475.0 & 480.0 & 480.0 & 480.0 & 480.0 & 480.0 & $0.2 \%$ \\
\hline $\begin{array}{c}\text { FL Resident } \\
\text { Dentistry } \\
\text { Headcount }\end{array}$ & & & & & & & & \\
\hline $\begin{array}{c}\text { Non-Res. } \\
\text { Dentistry } \\
\text { Headcount }\end{array}$ & & & & & & & & \\
\hline $\begin{array}{c}\text { Total } \\
\text { Dentistry } \\
\text { Headcount }\end{array}$ & & & & & & & & \\
\hline $\begin{array}{c}\text { FL Resident } \\
\text { Veterinary } \\
\text { Headcount }\end{array}$ & & & & & & & & \\
\hline $\begin{array}{l}\text { Non-Res. } \\
\text { Veterinary } \\
\text { Headcount }\end{array}$ & & & & & & & & \\
\hline $\begin{array}{c}\text { Total } \\
\text { Veterinary } \\
\text { Headcount }\end{array}$ & & & & & & & & \\
\hline $\begin{array}{c}\text { FL Resident } \\
\text { Pharmacy } \\
\text { Headcount }\end{array}$ & 0 & 0 & & 50.0 & 225.0 & 375.0 & 400.0 & $140.0 \%$ \\
\hline $\begin{array}{l}\text { Non-Res. } \\
\text { Pharmacy } \\
\text { Headcount }\end{array}$ & & 0 & & - & - & - & - & $0.0 \%$ \\
\hline $\begin{array}{c}\text { Total } \\
\text { Pharmacy } \\
\text { Headcount }\end{array}$ & 0 & 0 & & 50.0 & 225.0 & 375.0 & 400.0 & $140.0 \%$ \\
\hline
\end{tabular}

[This medical headcount is MD-only, not all HSC enrollments.] 

more than 150 FTE State-fundable enrollments

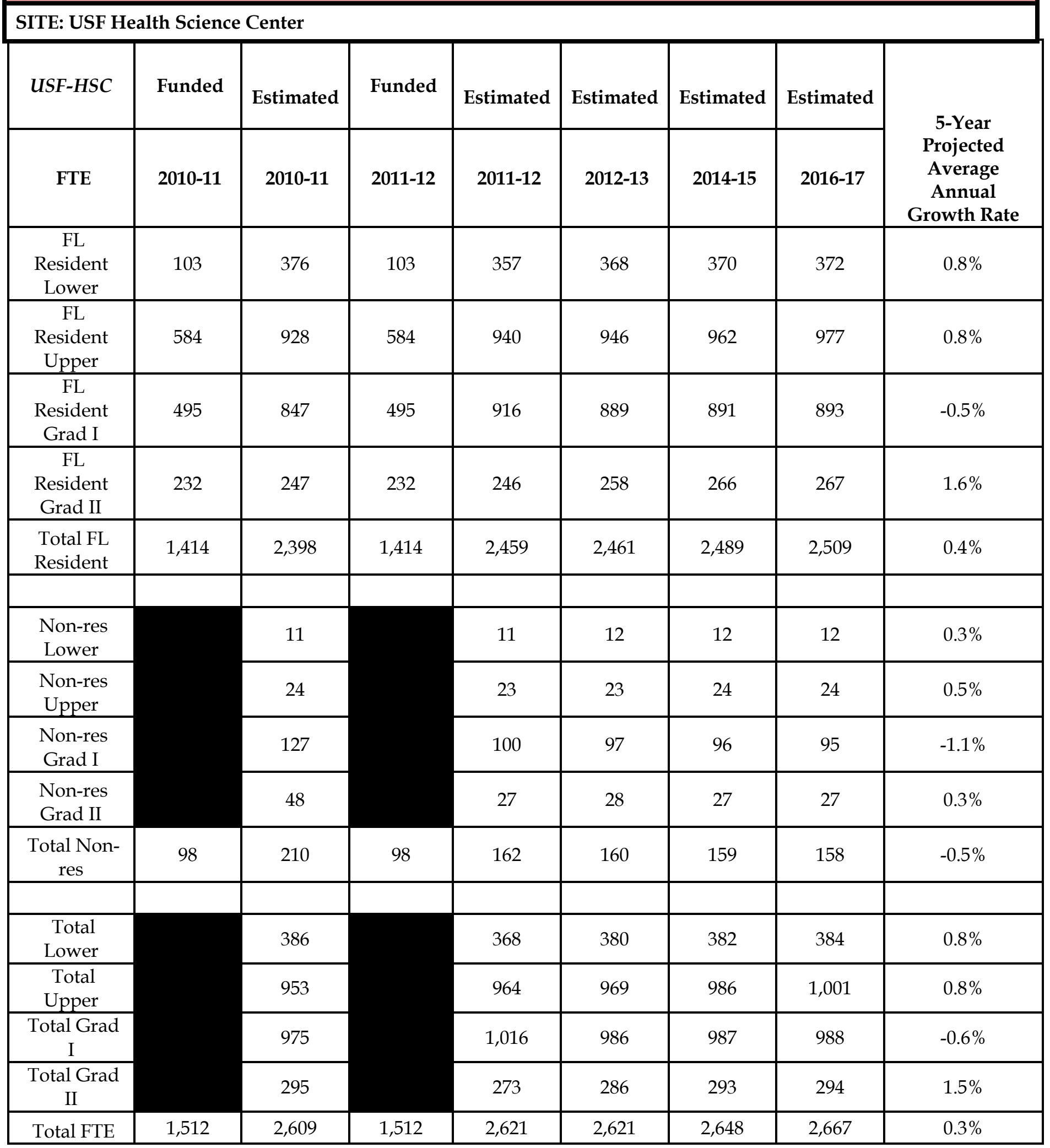


For the sum of the remaining physical locations with fewer than 150 current or planned State-fundable FTE enrollments.

SITE: REMAINING PHYSICAL LOCATIONS

\begin{tabular}{|c|c|c|c|c|c|c|}
\hline & Estimated & Estimated & Estimated & Estimated & Estimated & $\begin{array}{c}5-\text { Year } \\
\text { Projected } \\
\text { Average } \\
\text { Annual } \\
\text { GTE }\end{array}$ \\
\cline { 2 - 7 } & $2010-11$ \\
\hline Lower & & $2011-12$ & $2012-13$ & $2014-15$ & $2016-17$ & \\
\hline Upper & & & & & & \\
\hline Grad I & & & & & & \\
\hline Grad II & & & & & & \\
\hline Total & & & & & & \\
\hline
\end{tabular}

For the sum of current or planned State-fundable FTE enrollments not served at a physical location.

SITE: VIRTUAL INSTRUCTION / DISTANCE LEARNING

\begin{tabular}{|c|c|c|c|c|c|c|}
\hline & Estimated & Estimated & Estimated & Estimated & Estimated & \\
\hline FTE & 2010-11 & 2011-12 & 2012-13 & 2014-15 & 2016-17 & $\begin{array}{c}\text { Average } \\
\text { Annual } \\
\text { Growth Rate }\end{array}$ \\
\hline Lower & 938 & 966 & 995 & 1056 & 1120 & $3 \%$ \\
\hline Upper & 1,529 & 1575 & 1622 & 1721 & 1826 & $3 \%$ \\
\hline Grad I & 479 & 493 & 508 & 539 & 572 & $3 \%$ \\
\hline Grad II & 191 & 197 & 203 & 215 & 228 & $3 \%$ \\
\hline Total & 3,137 & 3,231 & 3,328 & 3,531 & 3,746 & $3 \%$ \\
\hline
\end{tabular}


Primary Institutional Goals/Metrics for the Next One to Three Years (In the context of the institutional strategic plan and vision, as well as System priorities, present three (3) to five (5) goals on which university effort will be focused in the next one to three years. Describe each goal, including whether the goal is new or continuing, the strategies for achieving that goal, the timeline and metrics by which success will be measured, expected outcomes, and assumptions, including financial, upon which the projected outcomes are predicated.) Each university is asked to include one goal associated with improved

baccalaureate retention and graduation (e.g., improved first-year retention; reduce attainment gaps for underrepresented groups; improve graduation rates for AA transfers; etc.).

\begin{tabular}{|c|c|c|}
\hline $\begin{array}{c}\text { Institutional Goal } \\
\text { [Indicate whether NEW or } \\
\text { CONTINUING] }\end{array}$ & Implementation Strategies & Metric(s)/Timeline/Expected Outcomes \\
\hline $\begin{array}{l}\text { \#1 (Required) - IMPROVE } \\
\text { BACCALAUREATE RETENTION AND } \\
\text { GRADUATION } \\
\text { (Continuing) } \\
\text { USF has adopted a comprehensive } \\
\text { approach to promoting student success, } \\
\text { focusing on preparedness, affordability, } \\
\text { and student support services. }\end{array}$ & 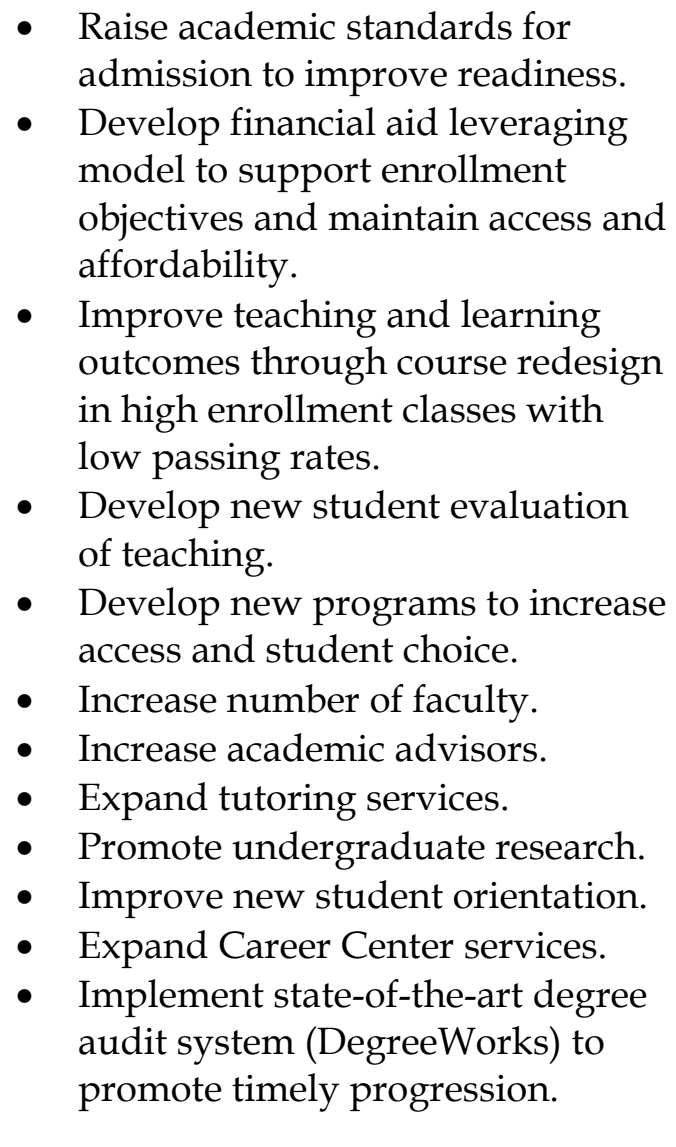 & $\begin{array}{l}\text { Metrics: } \\
\text { USF will monitor } \\
\text { - } \quad \text { Academic credentials of incoming students (High } \\
\text { - School GPA; SAT / ACT; Academic Success Factors). } \\
\text { - Access and Affordability metrics - Pell Grant and Bright } \\
\text { Futures recipients (number and percentage); Total Cost } \\
\text { of Attendance). } \\
\text { - Student Progression rates. } \\
\text { - } \quad \text { 6-year graduation rates. } \\
\text { - Student: Advisor ratio. } \\
\text { - Student utilization of tutoring and career services. } \\
\text { - Student credit hours per semester. } \\
\text { - Document undergraduate research. } \\
\text { - Student evaluations of teaching. } \\
\text { - Document number of new faculty. } \\
\text { - Document number of new advisors. } \\
\text { Timeline: } \\
\text { USF continues to monitor its retention and graduation rate } \\
\text { (http://www.ods.usf.edu/Plans/PPA/matrix.htm). } \\
\text { Expected Outcomes: } \\
\text { Six year FTIC graduation rate of 55\% in three years. } \\
\text { Gradual rise in retention rates between all years. }\end{array}$ \\
\hline
\end{tabular}




\begin{tabular}{|c|c|c|c|c|c|c|c|c|c|}
\hline \multicolumn{4}{|c|}{ Proposed Funding Source: $2011-12$} & \multicolumn{6}{|c|}{ Proposed Funding Source: $2012-13$} \\
\hline \multirow[t]{2}{*}{$\begin{array}{l}\text { State/ Tuition } \\
\text { Revenue (est.) }\end{array}$} & $\begin{array}{c}\text { Other } \\
\text { (Identify } \\
\text { Revenue } \\
\text { Source - } \\
\text { e.g., } \\
\text { Private) } \\
\end{array}$ & $\begin{array}{l}\text { Undergrad. } \\
\text { Tuition } \\
\text { Differential } \\
\text { Revenue (est.) }\end{array}$ & $\begin{array}{c}\text { Total } \\
\text { from } \\
\text { 2011-12 }\end{array}$ & $\begin{array}{c}\text { Undergrad. } \\
\text { Tuition } \\
\text { Differential } \\
\text { Revenue } \\
\text { (est.) }\end{array}$ & $\begin{array}{c}\text { Legislative } \\
\text { Budget } \\
\text { Request } \\
\text { (State Funds) }\end{array}$ & $\begin{array}{l}\text { State/ Tuition } \\
\text { Revenue (est.) }\end{array}$ & $\begin{array}{c}\text { Other } \\
\text { (Identify } \\
\text { Revenue } \\
\text { Source - e.g., } \\
\text { Private) }\end{array}$ & $\begin{array}{c}\text { Total from } \\
2012-13\end{array}$ & $\begin{array}{l}\text { 2012-13 to } \\
\text { 2016-17 PECO/ } \\
\text { Courtelis } \\
\text { Request }\end{array}$ \\
\hline & & $\$ 4.8 \mathrm{M}$ & $\$ 4.8 \mathrm{M}$ & $\$ 10.0 \mathrm{M}$ & $\$ 8.2 \mathrm{M}$ & & & $\$ 18.2 \mathrm{M}$ & \\
\hline \multicolumn{3}{|c|}{$\begin{array}{c}\text { Institutional Goal } \\
\text { [Indicate whether NEW or } \\
\text { CONTINUING] }\end{array}$} & \multicolumn{3}{|c|}{ Implementation Strategies } & \multicolumn{4}{|c|}{ Expected Outcomes/Metric(s)/Timeline } \\
\hline $\begin{array}{l}\text { \#2 Revenue En } \\
\text { Partnerships (C } \\
\text { USF continues } \\
\text { resource base t } \\
\text { sustainability } t \\
\text { mission. } \\
\text { These partners } \\
\text { Draper Labora } \\
\text { the Mote Marir } \\
\text { host to the Flor } \\
\text { Oceanography, } \\
\text { of Excellence fo } \\
\text { Identification a } \\
\text { (FCoEBITT/ C } \\
\text { partner in the } \\
\text { Consortium (F) }\end{array}$ & $\begin{array}{l}\text { ncement - } \\
\text { htinuing) } \\
\text { expand an } \\
\text { naintain fi } \\
\text { neet its dis } \\
\text { os include } \\
\text { y, SRI Inte } \\
\text { Research I } \\
\text { a Institute } \\
\text { ouses the I } \\
\text { Biomolecu } \\
\text { Targeted } \\
\text { I), and is } \\
\text { rida Energ } \\
\text { C). }\end{array}$ & $\begin{array}{l}\text { Public-Private } \\
\text { diversify its } \\
\text { ancial } \\
\text { nctive } \\
\text { ose ties with } \\
\text { aational, and } \\
\text { titute. USF is } \\
\text { orida Center } \\
r \\
\text { herapeutics } \\
\text { active } \\
\text { Systems }\end{array}$ & \multicolumn{3}{|c|}{$\begin{array}{l}\text { Develop external funding, private } \\
\text { giving, technology transfer and } \\
\text { public-private partnerships, } \\
\text { patents, licenses. } \\
\text { - Sponsor research to support } \\
\text { external funding, patents, } \\
\text { technology transfer, licensing } \\
\text { revenues, and start-ups. } \\
\text { - Champion endowment support } \\
\text { and foster partnerships with } \\
\text { research and industry. } \\
\text { Cultivate research/development } \\
\text { that strengthens Florida's economy } \\
\text { and contributes to global solutions. }\end{array}$} & \multicolumn{4}{|c|}{$\begin{array}{l}\text { Expected Outcomes: } \\
\text { Increased revenue and improved public-private } \\
\text { partnerships that enhance education and contribute to } \\
\text { employment opportunities to the state. } \\
\text { Metrics: } \\
\text { - Monitor external funding, private giving, technology } \\
\text { transfer and public-private partnerships, patents, } \\
\text { licenses. } \\
\text { - Document research to support external funding, } \\
\text { patents, technology transfer, licensing revenues, and } \\
\text { start-ups. } \\
\text { - Measure endowment support and partnerships with } \\
\text { research and industry. } \\
\text { Timeline: } \\
\text { These are on-going activities of USF, but over the next three } \\
\text { years, it is expected that significant research/development } \\
\text { will be undertaken that strengthens Florida's economy, } \\
\text { creates jobs, and contributes to global solutions. }\end{array}$} \\
\hline \multicolumn{4}{|c|}{ Proposed Funding Source: $2011-12$} & \multicolumn{6}{|c|}{ Proposed Funding Source: $2012-13$} \\
\hline $\begin{array}{l}\text { State/ Tuition } \\
\text { Revenue (est.) }\end{array}$ & $\begin{array}{c}\text { Other } \\
\text { (Identify } \\
\text { Revenue } \\
\text { Source - } \\
\text { e.g., } \\
\text { Private) } \\
\end{array}$ & $\begin{array}{l}\text { Undergrad. } \\
\text { Tuition } \\
\text { Differential } \\
\text { Revenue (est.) }\end{array}$ & $\begin{array}{l}\text { Total } \\
\text { from } \\
\text { 2011-12 }\end{array}$ & $\begin{array}{l}\text { Undergrad } \\
\text { Tuition } \\
\text { Differential } \\
\text { Revenue } \\
\text { (est.) }\end{array}$ & $\begin{array}{c}\text { Legislative } \\
\text { Budget } \\
\text { Request } \\
\text { (State Funds) }\end{array}$ & $\begin{array}{l}\text { State/ Tuition } \\
\text { Revenue (est.) }\end{array}$ & $\begin{array}{c}\text { Other } \\
\text { (Identify } \\
\text { Revenue } \\
\text { Source - e.g., } \\
\text { Private) }\end{array}$ & $\begin{array}{c}\text { Total from } \\
\text { 2012-13 }\end{array}$ & $\begin{array}{l}\text { 2012-13 to } \\
\text { 2016-17 PECO/ } \\
\text { Courtelis } \\
\text { Request }\end{array}$ \\
\hline & & & & & $\$ 4.0 \mathrm{M}$ & & & $\$ 4.0 \mathrm{M}$ & \\
\hline
\end{tabular}




\begin{tabular}{|c|c|c|c|c|c|c|c|c|c|}
\hline \multicolumn{3}{|c|}{$\begin{array}{c}\text { Institutional Goal } \\
\text { [Indicate whether NEW or } \\
\text { CONTINUING] }\end{array}$} & \multicolumn{3}{|c|}{ Implementation Strategies } & \multicolumn{4}{|c|}{ Expected Outcomes/Metric(s)/Timeline } \\
\hline \multicolumn{3}{|c|}{$\begin{array}{l}\text { \#3 Global Initiatives (Continuing) } \\
\text { USF has seen considerable increases in its } \\
\text { global activities, international faculty } \\
\text { exchanges, recruitment of fee-paying } \\
\text { international students and student study } \\
\text { abroad programs, thus adding to Florida's } \\
\text { place in the global economy and } \\
\text { employment opportunities. Its partnership } \\
\text { with INTO has internationalized the } \\
\text { campus. School for Global Sustainability } \\
\text { has been established and will be developed } \\
\text { further. USF World will be further } \\
\text { enhanced. }\end{array}$} & \multicolumn{3}{|c|}{$\begin{array}{l}\text { Brand and highlight USF World as } \\
\text { an integral part of the curriculum } \\
\text { and research endeavors at USF. } \\
\text { - Foster international faculty } \\
\text { exchanges, recruitment of fee- } \\
\text { paying international students and } \\
\text { student study abroad programs, } \\
\text { thus adding to Florida's place in } \\
\text { the global economy. } \\
\text { - Promote USF:INTO program. } \\
\text { - Continue to increase the number of } \\
\text { international students on campus. } \\
\text { Develop School for Global } \\
\text { Sustainability and facilitate } \\
\text { international programs. } \\
\text { Advance Global Academic } \\
\text { Partners program. }\end{array}$} & \multicolumn{4}{|c|}{$\begin{array}{l}\text { Expected outcomes: } \\
\text { Increased international involvement across the campus } \\
\text { with greater exchange of students with other countries. The } \\
\text { goal is to make Florida students more competitive at the } \\
\text { global level for employment opportunities. } \\
\text { Metrics: } \\
\text { - Monitor global activities, international faculty } \\
\text { exchanges, recruitment of fee-paying international } \\
\text { students and student study abroad programs, thus } \\
\text { adding to Florida's place in the global economy. } \\
\text { - Document progress with USF:INTO partnership } \\
\text { program. } \\
\text { - Monitor number of international students on campus. } \\
\text { Timeline: } \\
\text { This is an ongoing initiative, but gains are expected over } \\
\text { the next two years. }\end{array}$} \\
\hline \multicolumn{4}{|c|}{ Proposed Funding Source: $2011-12$} & \multicolumn{6}{|c|}{ Proposed Funding Source: $2012-13$} \\
\hline $\begin{array}{l}\text { State/ Tuition } \\
\text { Revenue (est.) }\end{array}$ & $\begin{array}{c}\text { Other } \\
\text { (Identify } \\
\text { Revenue } \\
\text { Source - } \\
\text { e.g., } \\
\text { Private) } \\
\end{array}$ & $\begin{array}{l}\text { Undergrad } \\
\text { Tuition } \\
\text { Differential } \\
\text { Revenue (est.) }\end{array}$ & $\begin{array}{c}\text { Total } \\
\text { from } \\
\text { 2011-12 }\end{array}$ & $\begin{array}{l}\text { Undergrad } \\
\text { Tuition } \\
\text { Differential } \\
\text { Revenue } \\
\text { (est.) }\end{array}$ & $\begin{array}{c}\text { Legislative } \\
\text { Budget } \\
\text { Request } \\
\text { (State Funds) }\end{array}$ & $\begin{array}{l}\text { State/ Tuition } \\
\text { Revenue (est.) }\end{array}$ & $\begin{array}{c}\text { Other } \\
\text { (Identify } \\
\text { Revenue } \\
\text { Source - e.g., } \\
\text { Private) }\end{array}$ & $\begin{array}{l}\text { Total from } \\
\text { 2012-13 }\end{array}$ & $\begin{array}{l}2012-13 \text { to } \\
\text { 2016-17 PECO/ } \\
\text { Courtelis } \\
\text { Request }\end{array}$ \\
\hline & & & & & $\$ 2.0 \mathrm{M}$ & & & $\$ 2.0 \mathrm{M}$ & \\
\hline
\end{tabular}


OPTIONAL: Universities may add one or two additional goals.

\begin{tabular}{|c|c|c|c|c|c|c|c|c|c|}
\hline \multicolumn{3}{|c|}{$\begin{array}{c}\text { Institutional Goal } \\
\text { [Indicate whether NEW or } \\
\text { CONTINUING] }\end{array}$} & \multicolumn{3}{|c|}{ Implementation Strategies } & \multicolumn{4}{|c|}{ Expected Outcomes/Metric(s)/Timeline } \\
\hline \multicolumn{3}{|c|}{$\begin{array}{l}\text { \#4 Technological and Innovative } \\
\text { Advances - Marine and Coastal } \\
\text { Environments - Health (Continuing/New } \\
\text { Elements): } \\
\text { An identified area of strategic focus, } \\
\text { Marine Science and Coastal Technologies } \\
\text { represents a key area, as demonstrated by } \\
\text { the rapid response to the Gulf Oil spill of } \\
\text { 2010. Technological advances have been } \\
\text { further enhanced through the innovative } \\
\text { USF Health initiatives such as the Center } \\
\text { for Advanced Medical Learning and } \\
\text { Simulation. }\end{array}$} & \multicolumn{3}{|c|}{$\begin{array}{l}\text { To enhance these initiatives, USF will: } \\
\text { - Develop initiatives in the health } \\
\text { sciences such as the technology-based } \\
\text { Center for Advanced Medical } \\
\text { Learning and Simulation (CAMLS). } \\
\text { Encourage research activities in coastal } \\
\text { marine programs, and foster external } \\
\text { research projects (Tampa Bay region } \\
\text { is the largest marine research } \\
\text { community in the southeast); } \\
\text { Promote student recruitment, } \\
\text { involvement, graduation, and } \\
\text { placement in coastal employment. } \\
\text { USF is uniquely positioned to serve as the } \\
\text { intellectual hub for technological } \\
\text { advances and workforce development } \\
\text { within the health and coastal industries. }\end{array}$} & \multicolumn{4}{|c|}{$\begin{array}{l}\text { Expected outcomes: } \\
\text { Increased involvement in technological } \\
\text { developments and innovations within the health and } \\
\text { coastal industries. CAMLS will attract industry } \\
\text { leaders and medical experts from around the world } \\
\text { creating a national center for transforming medical } \\
\text { education and a hub for biomedical research in the } \\
\text { downtown area with more job opportunities. } \\
\text { Metrics: } \\
\text { Marine environments - USF will monitor: } \\
\text { - Student recruitment. } \\
\text { - Student engagement. } \\
\text { - Student graduation. } \\
\text { - Student placement. } \\
\text { - External research funding. } \\
\text { Health - USF will monitors CAMLS: } \\
\text { - Health partnerships. } \\
\text { - Doctors trained. } \\
\text { Timeline: } \\
\text { While some immediate outcomes are expected from } \\
\text { the recent research activities associated with the Gulf } \\
\text { oil spill, this is a long-term USF goal to develop a } \\
\text { high quality coastal research and education } \\
\text { initiative. } \\
\text { Training of doctors from across the nation will begin } \\
\text { and continue. }\end{array}$} \\
\hline \multicolumn{4}{|c|}{ Proposed Funding Source: $2011-12$} & \multicolumn{6}{|c|}{ Proposed Funding Source: $2012-13$} \\
\hline $\begin{array}{l}\text { State/ Tuition } \\
\text { Revenue } \\
\text { ( st.) }\end{array}$ & $\begin{array}{c}\text { Other } \\
\text { (Identify } \\
\text { Revenue } \\
\text { Source - e.g., } \\
\text { Private) } \\
\end{array}$ & $\begin{array}{c}\text { Undergrad } \\
\text { Tuition } \\
\text { Differential } \\
\text { Revenue } \\
\text { (est.) } \\
\end{array}$ & $\begin{array}{l}\text { Total from } \\
2011-12\end{array}$ & $\begin{array}{c}\text { Undergrad } \\
\text { Tuition } \\
\text { Differential } \\
\text { Revenue } \\
\text { (est.) } \\
\end{array}$ & $\begin{array}{c}\text { Legislative } \\
\text { Budget } \\
\text { Request } \\
\text { (State Funds) }\end{array}$ & $\begin{array}{l}\text { State/ } \\
\text { Tuition } \\
\text { Revenue } \\
\text { (est.) }\end{array}$ & $\begin{array}{c}\text { Other } \\
\text { (Identify } \\
\text { Revenue } \\
\text { Source - } \\
\text { e.g., Private) } \\
\end{array}$ & $\begin{array}{c}\text { Total from } \\
2012-13\end{array}$ & $\begin{array}{l}2012-13 \text { to } \\
2016-17 \\
\text { PECO/ } \\
\text { Courtelis } \\
\text { Request } \\
\end{array}$ \\
\hline & & & & & $\$ 2.7 \mathrm{M}$ & & & $\$ 2.7 \mathrm{M}$ & \\
\hline
\end{tabular}




\begin{tabular}{|c|c|c|c|c|c|c|c|c|c|}
\hline \multicolumn{3}{|c|}{$\begin{array}{c}\text { Institutional Goal } \\
\text { [Indicate whether NEW or } \\
\text { CONTINUING] }\end{array}$} & \multicolumn{3}{|c|}{ Implementation Strategies } & \multicolumn{4}{|c|}{ Expected Outcomes/Metric(s)/Timeline } \\
\hline \multicolumn{3}{|c|}{$\begin{array}{l}\text { \#5 Community Engagement } \\
\text { (Continuing/New Elements): } \\
\text { USF is committed to furthering } \\
\text { community engagement and scholarship, } \\
\text { fostering social enterprise and global } \\
\text { collaborations in education, research and } \\
\text { service learning. }\end{array}$} & \multicolumn{3}{|c|}{$\begin{array}{l}\text { Establish a unified institutional structure } \\
\text { to facilitate and promote community } \\
\text { engagement, social enterprise, and global } \\
\text { collaborations in education, research and } \\
\text { service learning, including mechanisms } \\
\text { for managing fiscal and human resources } \\
\text { for student exchange, study abroad and } \\
\text { international field placement programs, } \\
\text { and faculty research, teaching, outreach } \\
\text { and professional development } \\
\text { opportunities. This will include: } \\
\text { - Development of an up-to-date } \\
\text { clearinghouse of information about all } \\
\text { engagement activities. } \\
\text { - Development of system to measure } \\
\text { community engagement. } \\
\text { - Encourage faculty participation in } \\
\text { community engagement -and include } \\
\text { community engagement in USF's } \\
\text { promotion and tenure guidelines. } \\
\text { - Encourage and reward student } \\
\text { community engagement and explore } \\
\text { feasibility of acknowledging } \\
\text { community engagement in official } \\
\text { transcripts. }\end{array}$} & \multicolumn{4}{|c|}{$\begin{array}{l}\text { Expected outcomes: } \\
\text { Greater involvement in community initiatives by } \\
\text { faculty and students. Increased institutional } \\
\text { efficiencies and job related activities. } \\
\text { Metrics: } \\
\text { - Document levels of community engagement of } \\
\text { faculty } \\
\text { - Document levels of community engagement of } \\
\text { students } \\
\text { - Change promotion and tenure policy on } \\
\text { community engaged scholarship. } \\
\text { - Recognize community engaged scholarship on } \\
\text { student transcripts. } \\
\text { Timeline: } \\
\text { This initiative is ongoing with elements } \\
\text { accomplished over a three period. WE expect } \\
\text { community engagement by students and faculty to } \\
\text { increase in this time frame. However, to change } \\
\text { promotion and tenure policy will require different } \\
\text { levels of discussion and approval. }\end{array}$} \\
\hline \multicolumn{4}{|c|}{ Proposed Funding Source: $2011-12$} & \multicolumn{6}{|c|}{ Proposed Funding Source: $2012-13$} \\
\hline $\begin{array}{l}\text { State/ Tuition } \\
\text { Revenue } \\
\text { ( st.) }\end{array}$ & $\begin{array}{c}\text { Other } \\
\text { (Identify } \\
\text { Revenue } \\
\text { Source - e.g., } \\
\text { Private) }\end{array}$ & $\begin{array}{c}\text { Undergrad } \\
\text { Tuition } \\
\text { Differential } \\
\text { Revenue } \\
\text { (est.) }\end{array}$ & $\begin{array}{l}\text { Total from } \\
2011-12\end{array}$ & $\begin{array}{c}\text { Undergrad } \\
\text { Tuition } \\
\text { Differential } \\
\text { Revenue } \\
\text { (est.) }\end{array}$ & $\begin{array}{l}\text { Legislative } \\
\text { Budget } \\
\text { Request } \\
\text { (State Funds) }\end{array}$ & $\begin{array}{l}\text { State/ } \\
\text { Tuition } \\
\text { Revenue } \\
\text { (est.) }\end{array}$ & $\begin{array}{c}\text { Other } \\
\text { (Identify } \\
\text { Revenue } \\
\text { Source - } \\
\text { e.g., Private) }\end{array}$ & $\begin{array}{l}\text { Total from } \\
2012-13\end{array}$ & $\begin{array}{c}2012-13 \text { to } \\
2016-17 \\
\text { PECO/ } \\
\text { Courtelis } \\
\text { Request }\end{array}$ \\
\hline & & & & & $\$ 2.0 \mathrm{M}$ & & & $\$ 2.0 \mathrm{M}$ & \\
\hline
\end{tabular}




\section{SUMMARY OF PROPOSED FUNDING FOR PRIMARY GOALS}

\begin{tabular}{|c|c|c|c|c|c|c|c|c|c|c|}
\hline \multicolumn{11}{|c|}{ SUMMARY OF PROPOSED FUNDING FOR PRIMARY GOALS } \\
\hline \multicolumn{5}{|c|}{ Proposed Funding Source: 2011-12 } & \multicolumn{6}{|c|}{ Proposed Funding Source: $2012-13$} \\
\hline Goal \# & $\begin{array}{c}\text { State/ } \\
\text { Tuition } \\
\text { Revenue } \\
\text { (est.) }\end{array}$ & $\begin{array}{c}\text { Other } \\
\text { (Identify } \\
\text { Revenue } \\
\text { Source - } \\
\text { e.g., } \\
\text { Private) } \\
\end{array}$ & $\begin{array}{l}\text { Undergrad } \\
\text { Tuition } \\
\text { Differential } \\
\text { Revenue } \\
\text { (est.) }\end{array}$ & $\begin{array}{c}\text { Total } \\
\text { from } \\
2011-12\end{array}$ & $\begin{array}{l}\text { Undergrad } \\
\text { Tuition } \\
\text { Differential } \\
\text { Revenue } \\
\text { (est.) }\end{array}$ & $\begin{array}{l}\text { Legislative } \\
\text { Budget } \\
\text { Request } \\
\text { (State } \\
\text { Funds) }\end{array}$ & $\begin{array}{l}\text { State/ Tuition } \\
\text { Revenue (est.) }\end{array}$ & $\begin{array}{c}\text { Other } \\
\text { (Identify } \\
\text { Revenue } \\
\text { Source - e.g., } \\
\text { Private) }\end{array}$ & $\begin{array}{c}\text { Total from } \\
2012-13\end{array}$ & $\begin{array}{c}2012-13 \text { to } \\
2016-17 \\
\text { PECO/ } \\
\text { Courtelis } \\
\text { Request }\end{array}$ \\
\hline 1 & & & $\$ 4.8 \mathrm{M}$ & $\$ 4.8 \mathrm{M}$ & $\$ 10.0 \mathrm{M}$ & $\$ 8.2 \mathrm{M}$ & & & $\$ 18.2 \mathrm{M}$ & \\
\hline 2 & & & & & & $\$ 4.0 \mathrm{M}$ & & & $\$ 4.0 \mathrm{M}$ & \\
\hline 3 & & & & & & $\$ 2.0 \mathrm{M}$ & & & $\$ 2.0 \mathrm{M}$ & \\
\hline 4 optional & & & & & & $\$ 2.7 \mathrm{M}$ & & & $\$ 2.7 \mathrm{M}$ & \\
\hline 5 optional & & & & & & $\$ 2.0 \mathrm{M}$ & & & $\$ 2.0 \mathrm{M}$ & \\
\hline Total & & & $\$ 4.8 \mathrm{M}$ & $\$ 4.8 \mathrm{M}$ & $\$ 10.0 \mathrm{M}$ & $\$ 18.9 \mathrm{M}$ & & & $\$ 28.9 \mathrm{M}$ & \\
\hline
\end{tabular}




\section{0 - 2011 Tuition Differential Update}

Provide the following information for the 2010-2011 Academic Year.

2010-2011 - 70\% Initiatives (List the initiatives

provided in the 2010-11 tuition differential request.)

Increase course offerings $(\$ 884,480)$

Improve graduation rates $(\$ 686,966)$

Increase the percentage of undergraduate students who are taught by faculty $(\$ 3,481,076)$

Decrease student-faculty ratios $(\$ 3,900,193)$
University Update on Each Initiative

Fall 2010 there were 263 additional sections taught compared to Fall 2009 which has increased accessibility.

There has been a notable change graduation rates; they were $48 \%$ in 2009 and have risen three points to $51 \%$ in 2010.

There has been an increase in the percentage of undergraduates taught by faculty, in accessibility, and in the number of degrees awarded.

The student population increased over the last five years, even though resources were invested in faculty so the student to faculty ratio has remained relatively stable at 27:1.

\section{Additional Detail, Where Applicable:}

Total Number of Faculty Hired or Retained (funded by tuition differential):

Over 40 new faculty and instructors have been hired.

Total Number of Advisors Hired or Retained (funded by tuition differential):

18 new advisors hired

Total Number of Course Sections Added or Saved (funded by tuition differential):

263

2010-2011 - 30\% Initiatives (list the initiatives

provided in the 2010-11 tuition differential request)

University Update on Each Initiative

The $30 \%$ portion is managed at the USF System level.

1. We will continue to target our need based grant awards to students who are paying the differential charges. Total expenditures: $\$ 3,096,920$

2. Because we continue to experience an increase in FAFSA filers who have need, the differential revenue will prevent dilution of the need based funds that are being awarded to an increasing number of students. Total expenditures: $\$ 1,032,307$

\section{Additional Information (estimates as of April 30, 2011):}

Unduplicated Count of Students Receiving at least one Tuition Differential-Funded Award:

\$ Mean (per student receiving an award) of Tuition Differential-Funded Awards:

\$ Minimum (per student receiving an award) of Tuition Differential-Funded Awards:

\$ Maximum (per student receiving an award) of Tuition Differential-Funded Awards:
3,256

$\$ 1,187$

$\$ 160$

$\$ 2,882$ 


\section{Fall 2011 Request for an Increased Tuition Differential Fee}

\section{University: University of South Florida}

\section{Effective Date}

University Board of Trustees Approval Date:

June 2011

Campus or Center Location

Campus or Center Location to which the Tuition

Differential fee will apply (If the entire university, indicate as such):

Undergraduate Course(s)

Course(s). (If the tuition differential fee applies to

all university undergraduate courses, indicate as

such. If not, also provide a rationale for the

differentiation among courses):

Current and Proposed Increase in the Tuition Differential Fee

Current Undergraduate Tuition Differential per credit hour:

Percentage tuition differential fee increase

(calculated as a percentage of the sum of base tuition plus tuition differential):

$\$$ Increase in tuition differential per credit hour:

$\$$ Increase in tuition differential for 30 credit hours:

Undergraduate courses offered by USF

\section{University of South Florida}

Undergraduate courses offered by USF

Projected Differential Revenue Generated and Intended Uses

Incremental differential fee revenue generated in

2011-12 (projected):

$\$ 22.00$

Total differential fee revenue generated in 2011-12

(projected):

$\$ 6,889,051$

$\$ 22,212,909$ 


\section{STATE UNIVERSITY SYSTEM OF FLORIDA \\ Tuition Differential Collections, Expenditures, and Available Balances \\ University of South Florida - Tampa \\ Fiscal Year 2010-2011 and 2011-12}

\section{University Tuition Differential}

Budget Entity: 48900100 (Educational \& General)

SF/Fund: 2 164xxx (Student and Other Fees Trust Fund)

Estimated Actual*

2010-11

Balance Forward from Prior Periods

Balance Forward

Less: Prior-Year Encumbrances

Beginning Balance Available:

\section{Receipts / Revenues}

Tuition Differential Collections

Interest Revenue - Current Year

Interest Revenue - From Carryforward Balance

Total Receipts / Revenues:

\section{Expenditures}

Salaries \& Benefits

Other Personal Services

Expenses

Operating Capital Outlay

Student Financial Assistance

Expended From Carryforward Balance

**Other Category Expenditures

Total Expenditures:

Ending Balance Available:

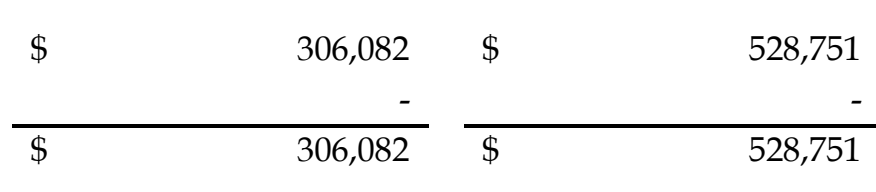

\begin{tabular}{crrrr} 
\$ & $12,584,925$ & & $19,497,249$ \\
22,099 & & 34,237 \\
& 537 & & 928 \\
\cline { 1 - 2 } & $12,607,561$ & & $\$$
\end{tabular}

\begin{tabular}{|c|c|c|c|}
\hline \multirow[t]{5}{*}{$\$$} & $\begin{array}{r}8,497,897 \\
80,500\end{array}$ & $\$$ & $\begin{array}{r}13,491,646 \\
100,000\end{array}$ \\
\hline & - & & - \\
\hline & - & & - \\
\hline & $3,784,293$ & & $5,858,803$ \\
\hline & 22,202 & & 526,776 \\
\hline$\$$ & $12,384,892$ & $\$$ & $19,977,225$ \\
\hline$\$$ & 528,751 & $\$$ & 83,940 \\
\hline
\end{tabular}

*Since the 2010-11 year has not been completed, provide an estimated actual.

**Provide details for "Other Categories" used. 


\section{State University System \\ Education and General \\ 2012-2013 Legislative Operating Budget Issue \\ Form I}

\begin{tabular}{|c|c|}
\hline University: & University of South Florida \\
\hline Work Plan Issue Title: & $\begin{array}{l}\text { Program Access and Degree Production } \\
\text { in STEM Fields }\end{array}$ \\
\hline Priority Number & 1 \\
\hline Recurring Funds Requested: & $\$ 8,217,981$ \\
\hline Non-Recurring Funds Requested: & $\$$ \\
\hline Total Funds Requested: & $\$ 8,217,981$ \\
\hline
\end{tabular}

\section{Description:}

USF continues to prepare the nation's next generation of leaders, thinkers, and scientists by replenishing the ranks of the professoriate for American higher education and placing its graduates in competitive professional programs.

Faculties are the core of the instructional mission. The key performance indicator (KPI) of students to faculty serves as a nationally accepted benchmark for the adequacy of faculty resources. The SUS data indicate that USF has the second highest student-to-faculty ratio among the 11 institutions and the highest ratio of the three public Florida institutions classified as Research Universities, Very High Research Activity (RU/VH) by the Carnegie Foundation for the Advancement of Teaching. An extraction from the IPEDS database of public RU/VH institutions demonstrates that USF has the highest student-to-faculty ratio nationally.

These faculties will contribute to enhanced numbers of graduates in the high impact STEM disciplines. In addition, these faculties are among the highest producers of grants and contracts, contributing to not only increased research funding but also providing stimulus for hightechnology, high-wage jobs.

Aligned with the vision of the New Florida initiative for the state of Florida to create a new state economy based on knowledge and innovation, USF stimulates innovation and the knowledge-based economy in Florida through (i) recruitment, development and retention of highly talented faculty and students; (ii) development of externally funded, basic and applied research leading to economic growth and new job creation; and (iii) public-private partnerships that attract new companies and venture capital. 
USF continues to be among the leaders of STEM field graduates in Florida. During the period 2004-05 to 2008-09, STEM programs (degree production) increased close to $40 \%$. The array of programs, especially the interdisciplinary nature of faculty and program collaboration, is a very positive environment. The recent "Industry Cluster Analysis of the Tampa Bay Region" published by Scripps Research Institute (SRI) identified five high-potential clusters for investment and growth: life sciences and medical services; research and engineering services; financial services; information technology services (with electronics); and aerospace, defense, and national security. The economy of the region is poised to make dramatic impacts in these areas. Likewise, these industry clusters reflect the strengths of USF. The state's investment in faculty coupled with the business conditions and climate make for a particularly strong synergy toward accomplishing the goals of New Florida.

While there will be some expansion of program depth and the provision for service and outreach, this is fundamentally an expansion of existing programs and services.

STEM disciplines are a strength of the university. Faculties are generally under resourced and must be augmented. Departments are established and highly productive. Administrative and support services are adequate and are in place. The university will provide start-up funding as appropriate. Student demand is high. Therefore an investment will make direct impacts.

\section{Return on Investment:}

1. Number of Headcount Students receiving services or participating in the program by year, for the next five years:

\begin{tabular}{|r|r|r|r|r|r|}
\hline & Year 1 & Year 2 & Year 3 & Year 4 & Year 5 \\
\hline & 280 & 560 & 875 & 875 & 875 \\
\hline
\end{tabular}

2. Number of FTE Students receiving services or participating in the program by year for the next five years:

\begin{tabular}{|c|c|c|c|c|c|}
\hline & Year 1 & Year 2 & Year 3 & Year 4 & Year 5 \\
\hline & 200 & 400 & 650 & 650 & 650 \\
\hline
\end{tabular}


3. Additional degrees, if any, produced as a result of this initiative: (Indicate the additional number of Bachelor's, Master's, Doctoral, \& Professional degrees to be produced by school year.)

\begin{tabular}{|l|l|l|l|l|l|l|l|}
\hline & Year 1 & Year 2 & Year 3 & Year 4 & Year 5 & Year 6 & Year 7 \\
\hline B & & & & 100 & 200 & 350 & 525 \\
\hline M & & & & 35 & 35 & 40 & 40 \\
\hline D & & & & & & 6 & 10 \\
\hline
\end{tabular}

\section{Facilities:}

A. Does this issue require an expansion or construction of a facility? $\mathrm{NO}$

B. If yes, is the project identified on the Capital Improvement List? If so, identify the project, fiscal amount, year requested, and priority number.

\begin{tabular}{|l|c|c|c|}
\hline & Facility Project Title & Fiscal Year & Amount Requested \\
\hline 1. & & & \\
\hline 2. & & & \\
\hline
\end{tabular}




\section{State University System \\ Education and General \\ 2012-2013 Legislative Operating Budget Issue \\ Form I}

\begin{tabular}{|c|c|}
\hline University: & University of South Florida \\
\hline Work Plan Issue Title: & $\begin{array}{l}\text { Competitive PhD Student Recruitment } \\
\text { in STEM Fields }\end{array}$ \\
\hline Priority Number & 2 \\
\hline Recurring Funds Requested: & $\$ 3,047,806$ \\
\hline Non-Recurring Funds Requested: & $\$$ \\
\hline Total Funds Requested: & $\$ 3,047,806$ \\
\hline
\end{tabular}

\section{Description:}

USF provides access to an array of university experiences. As a RU/VH campus in Tampa, the University offers a range of experiences through cooperative programs, innovative courses, interdisciplinary initiatives and research opportunities. At the graduate level, impressive trends can be seen with regard to the number of doctoral degrees awarded, a measure of USF's growing commitment to graduate education and the creation of new knowledge through research, scholarship, and creative activity.

Doctoral students contribute directly to the research and instructional productivity of the university. The recruitment of highly qualified doctoral students is essential to the fabric and culture of a research university. To attract the best graduate students, the university must be able to offer viable support packages in this highly competitive environment.

As a catalyst for change, New Florida recognizes the basic requirement of attracting the best of brightest of the knowledge workers to Florida's universities.

During the period of academic year 2004-05 to academic year 2008-09, USF has experienced a $49 \%$ expansion in its Ph.D. graduates, growing from a base of 194 research and professional doctoral degrees awarded to 400 .

The university has found resources to support doctoral programming growth by building on the overhead return from grants and contracts and by diverting funds from other priorities. USF graduate programming, especially for doctoral programs, should approximate the same level as other SUS $\mathrm{RU} / \mathrm{VH}$ universities. 


\section{Return on Investment}

Number of Headcount Students receiving services or participating in the program by year, for the next five years:

\begin{tabular}{|l|l|l|l|l|}
\hline Year 1 & Year 2 & Year 3 & Year 4 & Year 5 \\
\hline 110 & 110 & 110 & 110 & 110 \\
\hline
\end{tabular}

Additional degrees, Doctoral

\begin{tabular}{|l|l|l|l|l|}
\hline Year 5 & Year 6 & Year 7 & Year 8 & Year 9 \\
\hline 30 & 40 & 40 & 40 & 40 \\
\hline
\end{tabular}

Other outcomes:

The university will also realize increased $\mathrm{SCH}$ by those doctoral students with instructional responsibilities.

\section{Facilities:}

B. Does this issue require an expansion or construction of a facility?

No

\begin{tabular}{|l|c|l|l|}
\hline & Facility Project Title & Fiscal Year & Amount Requested \\
\hline 1. & & & \\
\hline 2. & & & \\
\hline
\end{tabular}




\section{State University System \\ Education and General \\ 2012-2013 Legislative Operating Budget Issue \\ Form I}

\begin{tabular}{|c|c|}
\hline University: & University of South Florida \\
\hline Work Plan Issue Title: & Clinical Translational Sciences Institute \\
\hline Priority Number & 3 \\
\hline Recurring Funds Requested: & $\$ 1,061,000$ \\
\hline Non-Recurring Funds Requested: & $\$ 0$ \\
\hline Total Funds Requested: & $\begin{array}{l}\mathbf{\$ 1 , 0 6 1 , 0 0 0} \\
\text { (Note: Priority } 1 \text { contains } \$ 1,041,366 \text { for this issue - } \\
\text { for a total of } \$ 2,102,366 \text { to complete this issue as } \\
\text { described) }\end{array}$ \\
\hline
\end{tabular}

\section{Description:}

This request for the USF Clinical Translational Sciences Institute (CTSI) is driven by Goal 3, (Building World-Class Academic Programs and Research Capacity) of USF's Strategic Plan. This initiative complements the research in USF Health's public health, nursing, physical therapy and pharmacy programs. It also supports the Clinical and Translational Science Award application USF Health submitted in Fall 2010 to NIH, which will advance interdisciplinary research across disciplines and hasten the translation of laboratory findings to clinical practice.

The requested funding for the CTSI will enable USF to create and support a seamless process for interdisciplinary clinical and translational research across a regional research network that will lead to increased research funding from the National Institutes of Health and industry sponsors. These efforts will enhance USF's institutional profile in the area of clinical and translational research, will provide a platform for innovative, collaborative educational programs in health fields and will support community participation in research.

Performing interdisciplinary research needed to address complex health issues of our population has become increasingly complicated. New technological tools outpace the ability to integrate and interpret their findings and the translation of new findings to human trials is challenging. The NIH has developed a national network of funded institutions to address this issue. The competitive grant application requires demonstrated institutional support and infrastructure. Institutions that cannot show this capacity will be at a competitive 
disadvantage. This is an instance where federal funding agencies goals align with USF's strategic goals.

This budget issue will allow us to further the Goal of Building Research capacity at USF. It is expected that the investment of $\$ 1 \mathrm{M}$ in this activity will directly lead to a minimum return on investment of $200 \%$ per year. Funding this budget issue will increase both internal research capacity and the volume of externally funded research at USF.

The objectives of the New Florida initiative are to create a new economy based on knowledge and innovation. Investing in the CTSI will lead to faster implementation of medical breakthroughs, improvements in medical care and the overall health of the population of the state. Industry partners will be attracted to collaborate with USF due to the infrastructure and facilitation of research. These funds will also be leveraged as cost sharing against federal awards in accordance with the goals of the New Florida initiative.

The mission of the USF CTSI is to facilitate and accelerate innovative clinical and translational research with the goal of improving health outcomes and making life better for our community. The CTSI strives to be an efficient, coordinated resource that provides educational, technical and administrative support to strengthen the connection and create new ideas between scholars, clinical and translational investigators, industry and the community with the ultimate goal of translating research discoveries into practice. The institute is composed of faculty and investigators from across diverse academic disciplines with access to resources and tools needed to catalyze research.

The CTSI is an existing program providing education of junior faculty in clinical and translational research, investigator services such as biostatitical and study design support and some administrative support. CTSI faculty are in the process of submitting a request for funding from the National Institutes of Health that will further increase the capacity of the Center and make it a key stakeholder in the federal government's Research Roadmap Initiative. In the last year, the CTSI has undergone a planning process and is reengineering how clinical research is conducted at USF. Additional funding will allow the CTSI to expand services and develop linkages with other Florida SUS partners conducting clinical and translational research. In addition, this funding will create processes and capacity that will further enhance our funding applications to NIH and other clinical and translational research fundors. 
This budget request will allow for further development of a webportal that will serve researchers, patients and the community and connect collaborative groups. It will provide informatics support for meaningful interface between medical records and a research data warehouse and the development of a tissue and clinical sample repository core for the CTSI.

USF and USF Health leadership have identified the CTSI as a strategic initiative that will further enhance the University's reputation in the research community and increase institutional capacity in clinical and translational research.

Current initiatives to improve graduate education and post-doctoral training in the clinical disciplines will generate more users of CTSI services and lead to better trained investigators.

\section{Return on Investment:}

We anticipate that this additional funding will positively impact the Federal R\&D expenditure Dashboard Indicator, generating more competitive proposals which will lead to more funded grant projects. This funding will be leveraged to submit a competitive Clinical Translation Sciences Award application to the National Institutes of Health for $\$ 20 \mathrm{M}$ over five years. The additional research funding that USF will receive as a result of this investment will allow USF to support and train additional graduate students and junior faculty.

Projections include:

Additional Federal Academic Research and Development Expenditures

\begin{tabular}{|l|l|l|l|l|}
\hline $2013-2014$ & $2014-2015$ & $2015-2016$ & $2016-2017$ & $2017-2018$ \\
\hline$\$ 100,000$ & $\$ 500,000$ & $\$ 3,000,000$ & $\$ 7,000,000$ & $\$ 12,000,000$ \\
\hline
\end{tabular}

Additional Total Academic Research and Development Expenditures

\begin{tabular}{|l|l|l|l|l|}
\hline $2013-2014$ & $2014-2015$ & $2015-2016$ & $2016-2017$ & $2017-2018$ \\
\hline$\$ 200,000$ & $\$ 1,000,000$ & $\$ 5,000,000$ & $\$ 10,000,000$ & $\$ 15,000,000$ \\
\hline
\end{tabular}

Licenses and Options Executed

\begin{tabular}{|l|l|l|l|l|}
\hline $2013-2014$ & $2014-2015$ & $2015-2016$ & $2016-2017$ & $2017-2018$ \\
\hline 0 & 1 & 3 & 10 & 12 \\
\hline
\end{tabular}


Additional Doctoral Degrees Produced

\begin{tabular}{|l|l|l|l|l|}
\hline $2013-2014$ & $2014-2015$ & $2015-2016$ & $2016-2017$ & $2017-2018$ \\
\hline 0 & 2 & 4 & 7 & 10 \\
\hline
\end{tabular}

A strong Clinical and Translational Science Institute will attract competitive graduate students, faculty and industry partners. New partnerships will be developed with resultant workforce and economic enhancement. This national network will provide for increased collaboration and unique grant opportunities. Community based research will be enhanced through a pilot program and the community engagement core of the CTSI. The number of collaborative grants with other institutions and community partners will increase.

\section{Facilities:}

Does this issue require an expansion or construction of a facility? No 


\section{State University System \\ Education and General \\ 2012-2013 Legislative Operating Budget Issue \\ Form I}

\begin{tabular}{|c|c|}
\hline University: & University of South Florida \\
\hline Work Plan Issue Title: & $\begin{array}{l}\text { Increase Federal Research Expenditures } \\
\text { and Economic Impact }\end{array}$ \\
\hline Priority Number & 4 \\
\hline Recurring Funds Requested: & $\$ 4,872,788$ \\
\hline Non-Recurring Funds Requested: & $\$$ \\
\hline Total Funds Requested: & $\$ 4,872,788$ \\
\hline
\end{tabular}

\section{Description:}

As one of the leading research universities in the state of Florida, USF contributes significantly to the state's economy, evident by its $\$ 3.2$ billion economic impact on the region. USF maintains research as the centerpiece of the university's strategic plan; it is fundamental to the recruitment and retention of talented faculty and students, and gives the university distinction. The System is focused on five main strategic priorities: student success, research and innovation, community engagement, global literacy and impact, and integrated, interdisciplinary inquiry. USF has four internationally recognized research themes: sustainable healthy communities, integrated neurosciences, diabetes and autoimmune disorders, and drug design, development and delivery. Home to Florida's second public medical school, USF's focus on health education and research is a hallmark of USF's unique contributions to improving health care in Florida and across the nation .

The SUS Strategic Plan emphasizes the establishment of distinctive institutional missions, critical to the identity of the university. USF has focused on research as a pervasive driver to distinction. With a $213 \%$ increase between 2000-2007, no other American university grew its federal research enterprise at a faster rate than USF, according to the Chronicle of Higher Education. The latest data (2008) from the National Science Foundation (NSF) show USF ranked $43^{\text {rd }}$ for total research expenditures and $34^{\text {th }}$ for federal expenditures compared with all public higher education institutions in the country.

Aligned with the vision of the New Florida initiative of creating a new state economy based on knowledge and innovation, USF stimulates innovation and the knowledge-based economy through (i) recruitment, development 
and retention of highly talented faculty and students; (ii) development of externally funded, basic and applied research leading to economic growth and new job creation; and (iii) public-private partnerships that attract new companies and venture capital.

Partnerships include close ties with Draper Laboratory, SRI International, and Mote Marine Research Institute. USF is the host of the Florida Institute of Oceanography, houses the Florida Center of Excellence for Biomedical Identification and Targeted Therapeutics (FCoE-BITT), and is an active partner in the Florida Energy System Consortium (FESC).

These resources will be applied to recurring funding for approximately 33 faculty who will have a research agenda.

In addition to its research enterprise, USF research and innovation infrastructure is becoming increasingly robust as evidenced by the growing number of postdoctoral fellows (120\% increase between 2004-05 and 2008-09) and non-faculty researchers with doctorates (762\% increase between 2004-05 and 2008-09).

\section{Return on Investment}

In the first two to four years, the university expects to maintain the current level of research funding. An increase in research expenditures is anticipated for subsequent years.

\section{Facilities:}

C. Does this issue require an expansion or construction of a facility? $\mathrm{NO}$ 


\section{State University System \\ Education and General \\ 2012-2013 Legislative Operating Budget Issue \\ Form I}

\begin{tabular}{|c|c|}
\hline University: & University of South Florida \\
\hline Work Plan Issue Title: & $\begin{array}{l}\text { USF/UWF/Andrews Institute } \\
\text { Partnership Program in Physical } \\
\text { Therapy Education, Research \& Clinical } \\
\text { Care }\end{array}$ \\
\hline Priority Number & 5 \\
\hline Recurring Funds Requested: & $\$ 600,000$ \\
\hline Non-Recurring Funds Requested: & $\$ 0$ \\
\hline Total Funds Requested: & $\$ 600,000$ \\
\hline
\end{tabular}

\section{Description:}

The proposed expansion of the USF Health Doctor of Physical Therapy (DPT) Degree Program through a collaborative arrangement with the University of West Florida and the Andrews Institute is addressed in several of the 2010 University Work Plan strategies including the overview of core institutional strengths, special assets, and niche contributions that most appropriately address "access to and production of degrees - enhanced opportunities". Further, Goal 3 addressing Academic and Administrative Collaborations is a goal of this initiative. The focused direction of this plan also addresses "providing access to an array of high quality, globally competitive degree programs" and "meeting distinctive needs" of the region and state. The expansion of the DPT Degree Program will serve to meet the needs presented by Florida's increasing population of retirees, including Wounded Warriors, especially in the panhandle region of the State of Florida. There is a continual and growing student demand for this type of health professions education. Lastly, this proposal is part of the new academic degree program goals which are needed to align with the institutional strategic plan and system priorities.

The USF/UWF/Andrews Institute Partnership Program in Physical Therapy Education, Research \& Clinical Care is to Meet Statewide Professional and Workforce Needs.

The expansion of USF's the Doctor of Physical Therapy Degree Program will support the SUS Strategic Plan by educating additional physical therapists that will enter high skill/high-wage jobs deemed $\boldsymbol{a}$ critical 
workforce shortage by the Secretary of Health. Physical Therapists are projected to experience a $3.3 \%$ annual growth rate over the next decade in the state. In June, 2010, Physical Therapists were reported by the AWI as the $2^{\text {nd }}$ highest (only to Nursing) advertised occupation available in the state of Florida.

Selected Geography: Florida

Standard Occupational (SOC) Code: 291123

Standard Occupational (SOC) Title: Physical Therapists

Wages for Year 2010

\begin{tabular}{|c|c|c|}
\hline Entry & Average & Experienced \\
\hline$\$ 58,250.40$ & $\$ 80,382.61$ & $\$ 91,448.72$ \\
\hline
\end{tabular}

Occupational Projections

\begin{tabular}{|c|c|c|}
\hline $\begin{array}{c}\text { 2017 Projected } \\
\text { Employment }\end{array}$ & $\begin{array}{c}\text { Annual } \\
\text { Growth Rate }\end{array}$ & $\begin{array}{c}\text { Annual } \\
\text { Total Openings }\end{array}$ \\
\hline 15,064 & $3.30 \%$ & 528 \\
\hline
\end{tabular}

Source: Agency for Workforce Innovation - Labor Market Statistics

This LBR request specifically addresses the objectives of the New Florida initiative. The expansion of Florida's economy is to be structured around high-technology, high-wage jobs involving the fields of science, technology, engineering and mathematics (or "STEM"); this specifically includes the fields of medicine, health care and education which are tremendously vital to Florida's future economy. This LBR request is to enhance and build upon the academic strengths of the USF Health School of Physical Therapy and Rehabilitation Sciences.

The University of South Florida College of Medicine School of Physical Therapy \& Rehabilitation Sciences proposes to partner with the University of West Florida to provide qualified UWF graduates with guaranteed pathway/admissions into the USF SPTRS Doctor of Physical Therapy degree Program on the USF Tampa campus. This partnership program will allow the USF DPT degree program to expand to reserve up to twelve (12) future places in each first-year DPT class for UWF students who satisfy USF SPTRS requirements for admissions to the study of physical therapy. 
The University of South Florida College of Medicine School of Physical Therapy \& Rehabilitation Sciences proposes to partner with the University of West Florida and the Andrews Institute/APREI in complementary and collaborative research projects utilizing the combined human resources of UWF, AI/APREI and USF SPTRS faculty.

The University of South Florida College of Medicine School of Physical Therapy \& Rehabilitation Sciences proposes to partner with the University of West Florida and the Andrews Institute/APREI in clinical care and education acknowledging the expertise resident in the surgeons, physicians, therapists, certified athletic trainers and strength \& conditioning specialists at the institute.

UWF School of Allied Health and Life Sciences (SAHLS) has a solid track record in the allied health arena, offering the following list of programs: Master of Public Health degree (IVIPH); a BS in Health Sciences with 8 specializations covering Allied Health, Health Care Professional, Aging Studies, Health Care Administration, Health Communications, Health Care Ethics, Psychology of Health and Medical Information Technology; a RN to BSN; a four-year generic BSN; a Master of Science in Administration (MSA)-Nursing Administration specialization; a BOTapproved and soon to be implemented Master of Science in Nursing; and a BS in Clinical Laboratory Sciences. A set of graduate courses in health care ethics and in medical informatics support certificates in both these areas as well as providing elective credit toward the MPH and a MSA Biomedical/Pharmaceutical specialization.

Another set of graduate and undergraduate courses serve as electives in the MPH or BSHS and underwrite certificates in Emergency Management, Environmental Health, Infection Control and Occupational Safety and Health at the graduate level, and Occupational Safety and Health, and in Readiness and Response at the undergraduate level. In addition, SAHLS offers a mosaic of workshops on topics dictated by the education departments of regional hospitals and public health departments. All of these degrees, certificates and workshops enjoy strong support from the regional health care and public health communities in the form of funding, in-kind and direct involvement in the design and conduct of all offerings.

SAHLS has worked closely with high schools throughout the region to create "teflon" pathways for the best students from high school health academies into the full range of allied health programs offered by UWF. This design represents a pipeline for excellent students for ally professional school in the area. UWF also brings to the table over 300 
highly qualified undergraduate students in the UWF pre-professional program which is designed to prepare students for admission into professional schools and doctoral programs, and the BSHS which technology related to rehabilitation would be at their fingertips in one central location within AI's 12,000 sf outpatient rehabilitation facility.

\section{The USF Health School of Physical Therapy \& Rehabilitation Sciences} was established in 1998 by the Florida Board of Regents as a component of the USF College of Medicine and graduated its first class of MSPT students in 2001. As the first SUS physical therapist educational program to receive BOG authorization to implement the first-professional Doctor of Physical Therapy degree in late 2004, USF did so and graduated it's charter DPT class in 2008. Subsequent classes have graduated in 2009 and 2010 with graduates achieving NPTE Board examination scores well above the US average. The School received a reaffirmation of its CAPTE accreditation with commendation in 2008 through 2016. The School receives in excess of 250 applications for the current 36 seats available in each class cohort and has joined the Physical Therapy Centralized Application Service (PTCAS) for AY '10-'11. The School is supported by a core academic and clinical faculty of twenty (20) and an administrative staff of eight (8). The USF DPT curriculum is unique in its innovative, integrated, interprofessional blending of MD and DPT students in the first year foundational science and doctoring courses. Students complete their DPT degrees in 37 months and eight semesters of study, including 36 weeks of full-time clinical education. The School's total physical footprint is approximately 30,000 square feet, with 6,000 square feet dedicated to the Human Functional Performance Laboratory and 4,000 square feet dedicated to the USF Physical Therapy Center. All classrooms are wireless to support laptop computer use and fully media equipped. Classrooms are scalable to support as many as 48 students per class. As part of its Strategic Plan, the School will be implementing an ABPTS accredited clinical residency in the PT Center, partnering with Rehab Essentials, Inc to offer an on-line transitional DPT degree program for practicing physical therapists in Florida and continuing the planning for the future offering of a PhD degree in Rehabilitation Sciences. The School aspires to gain College status within the next five years.

\section{Return on Investment}

This LBR initiative will assist in meeting the following dashboard metrics and will help advance the research and academic reputation of the University:

- Research and Professional Doctorates Awarded, and 
- Degrees Awarded in Specified Health Profession Critical Need Areas.

4. Number of Headcount Students receiving services or participating in the program by year, for the next five years:

$\begin{array}{cc}\frac{\text { Fiscal }}{\text { Year }} & \\ 2012-13 & \text { Headcount } \\ 2013-14 & 24 \\ 2014-15 & 36 \\ 2015-16 & 36 \\ 2016-17 & 36\end{array}$

5. Number of FTE Students receiving services or participating in the program by year for the next five years:

$\begin{array}{cc}\frac{\text { Fiscal }}{\text { Year }} & \\ 2012-13 & \frac{\text { FTE }}{15} \\ 2013-14 & 30 \\ 2014-15 & 45 \\ 2015-16 & 45 \\ 2016-17 & 45\end{array}$

6. Additional degrees, if any, produced as a result of this initiative: (Indicate the additional number of Bachelor's, Master's, Doctoral, \& Professional degrees to be produced by school year.)

\begin{tabular}{|c|c|}
\hline Fiscal & Professiona \\
\hline Year & Degrees \\
\hline 2012-13 & 0 \\
\hline 2013-14 & 0 \\
\hline 2014-15 & 12 \\
\hline $2015-16$ & 12 \\
\hline 2016-17 & 12 \\
\hline
\end{tabular}

\section{Facilities:}


A. Does this issue require an expansion or construction of a facility? No.

2012-2013 LBR 


\section{State University System \\ Education and General \\ 2012-2013 Legislative Operating Budget Issue \\ Form I}

\begin{tabular}{|l|l|}
\hline $\begin{array}{l}\text { University: } \\
\text { Work Plan Issue Title: }\end{array}$ & $\begin{array}{l}\text { University of South Florida } \\
\text { USF Health Neurosciences and } \\
\text { Alzheimer's Disease Initiative }\end{array}$ \\
\hline $\begin{array}{l}\text { Priority Number } \\
\text { Recurring Funds Requested: }\end{array}$ & $\mathbf{6} 684,000$ \\
Non-Recurring Funds Requested: & $\mathbf{\$ 0}$ \\
Total Funds Requested: & $\mathbf{\$ 6 8 4 , 0 0 0}$ \\
& $\begin{array}{l}\text { (Note: Priority } 1 \text { contains } \$ 315,000 \text { for this issue for a } \\
\text { total of } \$ 1,000,000 \text { to complete the issue as described) }\end{array}$ \\
\hline
\end{tabular}

\section{Description:}

This Legislative Budget Request is to secure state funding for a strategically important research and education program of USF Health's related to neurosciences and specifically to Alzheimer's disease.

This request is addressed in several of the 2011 University Work Plan strategies including the overview of core institutional strengths, special assets, and niche contributions that most appropriately address developing "world class academic programs and research capacity" and "economic develop (new job creation)." The strategic directions of this plan also address "stimulating the innovation and knowledge-based economy in Florida," and "meeting distinctive needs of education and research" of Florida which are integral to USF Health.

The USF Health Neurosciences and Alzheimer's disease Initiative is to Build World-Class Academic Programs and Research Capacity. This effort will be accomplished through the following.

During the past several decades, researchers have made breathtaking progress in understanding the anatomy, cell biology, physiology and chemistry of the brain. Yet many basic mysteries remain, including how brain function translates into mental activity and why brain function declines with age. Recent advances in neuroimaging, genomics, computational neuroscience, engineering and other disciplines have placed scientists on the brink of continued successes in neuroscience with 
the expectation to make unprecedented discoveries regarding brain function in health, aging and disease.

Neurosciences research especially at the USF Health Byrd Alzheimer's Institute is of critical importance to USF Health, USF and Florida. The Byrd Institute serves as the state-wide focus for Alzheimer's Research, yet the Institute currently has no state allocation to advance its research and education programs. This LBR is to request state support to continue to advance the mission of the USF Health Byrd Alzheimer's Institute which is dedicated to the prevention, treatment and cure of Alzheimer's disease and related disorders.

This LBR request specifically addresses the objectives of the New Florida initiative. The expansion of Florida's economy is to be structured around high-technology, high-wage jobs involving the fields of science, technology, engineering and mathematics (or "STEM"); this specifically includes the fields of medicine, health care and education which are tremendously vital to Florida's future economy. This LBR request is to enhance and build upon the research and education strengths of USF Health Neurosciences and Alzheimer's disease research and to facilitate building an economy that provides the kind of jobs that lead to a robust quality of life for Floridians. This initiative helps to ensure that USF Health continues to maintain a strong and vibrant research programs and facilitates the expansion of ideas and discoveries that are so important to the State's economic development. Further, this important collaboration furthers helping to establish Florida as a major player of new knowledge development and innovation on the world stage.

With a state-of-the-art research and education building and a highly qualified team of researchers, physicians, clinicians and educators, the USF Health Byrd Alzheimer's Institute is at the forefront of Alzheimer's and related neurosciences disease research and care in Florida. The core missions of the Institute include:

- To conduct laboratory research to understand the changes in the brain that cause dementia and relate disorders, and to develop approaches for the prevention and treatment of Alzheimer's disease.

- To conduct clinical trials to test treatments for individuals with all stages of memory loss.

- Provide state-of-the-art diagnostic evaluations and the highest level of patient care to individuals with Alzheimer's disease and other memory problems. 
- Support family caregivers by providing educational programs, support groups, counseling and information.

- Provide education and training for healthcare professionals, service providers and students.

The USF Health Byrd Alzheimer's Research Institute provides an important focus for both research and education related to Alzheimer's and related neuroscience diseases. This LBR request will help the Institute recruit new faculty and provide support for additional post-doctoral and graduate student trainees. This initiative provides significant opportunities to expand our research efforts in biochemistry and cellular and molecular neuroscience, neural systems and computational neuroscience, behavioral neuroscience, developmental neuroscience, neuroimmunology, and neuropsychopharmacology, among others. This initiative compliments the research in USF Health's public health, nursing, physical therapy and pharmacy programs. It also supports the Clinical and Translational Science Award application USF Health is submitted to advance interdisciplinary research across disciplines to enhance laboratory findings to the clinical setting.

Numerous new medical discoveries and technologies are anticipated from this initiative. Thus, new start-up companies are expected and additional established pharmaceutical and medical companies are anticipated to either move or establish satellite facilities in the Tampa area as a result of this collaboration. Ultimately, the research, clinical practice, and education conducted by USF Health personnel at the Byrd Alzheimer's Institute will produce new discoveries and $21^{\text {st }}$ century "health professionals" to enable the delivery of cutting edge care to the citizens of Florida.

Our strategic research directions for the University include neurosciences, diabetes and autoimmune disorders, and globalization. We have a strong focus with the Moffitt Cancer Center regarding Cancer Research. We also have a strong developing research area of focus regarding drug development and delivery with our Center for Drug Development and Innovation. The University also has a Neurosciences Collaborative that cuts across USF and USF Health. Considerable collaboration already exists in this area of research and education, and this LBR will help to further expand and enhance this area of research. This initiative is expected to be integral to advancing this important University research initiative in the future.

\section{Return on Investment}


is LBR initiative will assist in meeting the following dashboard metrics and will help advance the research reputation of the University:

- Research and Professional Doctorates Awarded,

- Federal Academic Research and Development Expenditures,

- Total Academic Research and Development Expenditures, and

- Licenses and Options Executed

Projections include:

Additional Federal Academic Research and Development Expenditures

\begin{tabular}{|l|l|l|l|l|}
\hline $2013-2014$ & $2014-2015$ & $2015-2016$ & $2016-2017$ & $2017-2018$ \\
\hline$\$ 100,000$ & $\$ 300,000$ & $\$ 750,000$ & $\$ 3,000,000$ & $\$ 5,000,000$ \\
\hline
\end{tabular}

Additional Total Academic Research and Development Expenditures

\begin{tabular}{|l|l|l|l|l|}
\hline $2013-2014$ & $2014-2015$ & $2015-2016$ & $2016-2017$ & $2017-2018$ \\
\hline$\$ 150,000$ & $\$ 500,000$ & $\$ 1,000,000$ & $\$ 4,000,000$ & $\$ 7,000,000$ \\
\hline
\end{tabular}

Licenses and Options Executed

\begin{tabular}{|l|l|l|l|l|}
\hline $2013-2014$ & $2014-2015$ & $2015-2016$ & $2016-2017$ & $2017-2018$ \\
\hline 0 & 1 & 2 & 5 & 7 \\
\hline
\end{tabular}

Additional Doctoral Degrees Produced

\begin{tabular}{|l|l|l|l|l|}
\hline $2013-2014$ & $2014-2015$ & $2015-2016$ & $2016-2017$ & $2017-2018$ \\
\hline 0 & 2 & 3 & 5 & 7 \\
\hline
\end{tabular}

\section{Facilities:}

A. Does this issue require an expansion or construction of a facility? No 


\section{State University System \\ Education and General \\ 2012-2013 Legislative Operating Budget Issue \\ Form I}

\begin{tabular}{|l|l|}
\hline University: & University of South Florida \\
Work Plan Issue Title: & Cardiovascular Sciences Initiative \\
\hline Priority Number & 7 \\
$\begin{array}{l}\text { Recurring Funds Requested: } \\
\text { Non-Recurring Funds Requested: }\end{array}$ & $\mathbf{\$ 4 1 2 , 0 0 0}$ \\
Total Funds Requested: & $\mathbf{\$ 0}$ \\
& $\mathbf{\$ 4 1 2 , 0 0 0}$ \\
& $\begin{array}{l}\text { (Note: Priority } 1 \text { contains } \$ 338,000 \text { for this issue for a } \\
\text { total of } \$ 750,000 \text { to complete this issue as described) }\end{array}$ \\
\hline
\end{tabular}

\section{Description}

Cardiovascular disease is the number one cause of death in Florida and in the country. USF Health proposes to establish a Cardiovascular Research Institute that will leverage existing resources and serve as a foundation for recruiting new physicians and researchers who will focus on identifying new methods to diagnose and treat cardiovascular disease. The USF Health Cardiovascular Research Institute will concentrate on four areas that have been demonstrated to offer the greatest return in terms of bringing research discoveries from the laboratory to the patient bedside: Regenerative Medicine, Genomics, Vascular Biology and Diabetes. Heavy emphasis will be directed towards research focused on new therapies such as the use of stem cell and gene therapy to regenerate cardiac tissue and restore cardiac function to patients with a diagnosis of heart failure. Additional emphasis will be placed on genomic research and screening including the establishment of a large biorepository to store thousands of samples from patients with various forms of cardiovascular disease to assist in identifying diagnostic markers that will lead to the identification and treatment of patients who are at high risk.

\section{Return on Investment}

Given the current reality of cardiovascular disease (CVD) being the leading cause of death in the world (with expected further increases due to the aging US population), the creation of a Cardiovascular Research Institute will undoubtedly draw a significant number of new students interested in the field of CVD. This will include students looking for a career in medicine or looking for graduate programs in a number of areas 
such as bioengineering, public health, or molecular medicine. In addition, the Institute will enhance the current MD program by attracting medical students seeking excellent training in these areas. From a research perspective, the new therapies being developed such as the use of stem cells or gene therapy will only enhance this enthusiasm. Finally, the whole area of genomic screening leading to personalized medicine will appeal to a wide array of students and trainees that overall will enhance not only the number, but the caliber of our applicants.

III. Facilities (If this issue requires an expansion or construction of a facility and is on the Capital Improvement List complete the following table.):

\begin{tabular}{|c|c|c|r|c|}
\hline & Facility Project Title & $\begin{array}{c}\text { Fiscal } \\
\text { Year }\end{array}$ & $\begin{array}{c}\text { Amount } \\
\text { Requested }\end{array}$ & $\begin{array}{c}\text { Priority } \\
\text { Number }\end{array}$ \\
\hline 1. & USF Health Heart Institute & $2012-13$ & $\$ 6,893,188$ & \\
\hline 2. & USF Health Heart Institute & $2013-14$ & $\$ 42,235,000$ & \\
\hline 3. & USF Health Heart Institute & $2014-15$ & $\$ 1,020,000$ & \\
\hline
\end{tabular}

